Cognition, 41 (1991) 83-121

\title{
Learning to express motion events in English and Korean: The influence of language-specific lexicalization patterns*
}

\author{
Soonja Choi \\ Department of Linguistics, San Diego State University, 5178 College Ave., San Diego, CA 92182. \\ U.S.A.
}

Melissa Bowerman

Max Planck Institute for Psycholinguistics, Wundtlaan 1, 6525 XD Nijmegen, The Netherlands

\begin{abstract}
Choi, S., and Bowerman, M., 1991. Learning to express motion events in English and Korean: The influence of language-specific lexicalization patterns. Cognition, 41: 83-121.

English and Korean differ in how they lexicalize the components of motion events. English characteristically conflates Motion with Manner, Cause, or Deixis, and expresses Path separately. Korean, in contrast, conflates Motion with Path and elements of Figure and Ground in transitive clauses for caused Motion, but conflates motion with Deixis and spells out Path and Manner separately in intransitive clauses for spontaneous motion. Children learning English and Korean show sensitivity to language-specific patterns in the way they talk about motion from as early as 17-20 months. For example, learners of English quickly generalize their earliest spatial words - Path particles like up, down, and in - to both spontaneous and caused changes of location and, for up and down, to posture changes, while learners of Korean keep words for spontaneous and caused motion strictly separate and use different words for vertical changes of location and posture changes. These findings challenge the widespread view that children initially map spatial words directly to nonlinguistic spatial concepts, and suggest that they are influenced by the semantic organization of their language virtually from the beginning. We discuss how input and cognition may interact in the early phases of learning to talk about space.
\end{abstract}

"We would like to thank Herb Clark, Steve Pinker, Dan Slobin, and two anonymous reviewers for helpful comments on earlier drafts of this paper.

0010-0277/91/\$12.20 (C) 1991 - Elsevier Science Publishers B.V. 


\section{Introduction}

In recent studies of lexical semantics, the expression of motion and location has played a central role (Jackendoff, 1983, 1990; Levin, 1985; Talmy, 1975, 1985). Spatial meanings are clearly fundamental to human cognition, and the system for encoding them is important not only in its own right but also because it provides the core structuring principles for many meanings that are not fundamentally spatial.

Although all languages seem to analyze motion/location events into components such as Motion and Path, they differ both in how they combine these notions into words (Talmy, 1975, 1985) and in the categories of spatial relations they distinguish (Bowerman, 1989, 1991; Casad \& Langacker, 1985; Lakoff, 1987). The presence of both universality and language specificity allows us to raise basic questions about the relationship between nonlinguistic cognition and language input in children's acquisition of spatial expressions. Children are able to learn a great deal about space on a nonlinguistic basis (Gibson \& Spelke, 1983; Piaget \& Inhelder, 1956). But this nonlinguistic knowledge is not enough: children must still discover how spatial information is organized in their language. How do these two sources of structure interact in the course of language development?

Language specificity in semantic organization has rarely been considered in studies of the acquisition of spatial expressions. Most investigators have assumed that the meanings of spatial words like in, on, and under reflect nonlinguistic spatial concepts rather directly. This assumption has been a basis for a major hypothesis about the acquisition of spatial language: that children learn spatial terms by mapping them to concepts of space that they have formulated independently of language (e.g., H. Clark, 1973; Slobin, 1973).

The hypothesis of cognitive priority has found considerable support in research on the acquisition of spatial words. For example, children acquire English spatial prepositions and their counterparts in other languages in a relatively consistent order, and this order seems to reflect primarily the sequence in which the underlying spatial concepts are mastered (E. Clark, 1973; Johnston \& Slobin, 1979). Also, when researchers have compared children's nonlinguistic grasp of spatial concepts directly with their knowledge of the words that encode these meanings, they have invariably found an advantage for nonlinguistic knowledge (e.g., Corrigan, Halpern, Aviezer, \& Goldblatt, 1981; Halpern, Corrigan, \& Aviezer, 1981; Levine \& Carey, 1982). These findings have contributed not only to assumptions about spatial semantic development but also the rise of the more general "cognition hypothesis": that children initially identify words, inflections, and combination patterns with meanings formulated independently of language (see Cromer, 1974, for discussion). The findings are also consistent with Slobin's (1985) proposal that children map grammatical morphemes onto a starting set of universally shared meanings or "grammaticizable notions". 
Nonlinguistic spatial understanding is, then, important in the development of spatial words. But there is reason to doubt whether, as claimed, it directly provides spatial concepts to which words can be mapped (see also Van Geert, 1985/6). In examining early vocabularies across languages, Gentner (1982) found that words for relational meanings are consistently learned later than words for concrete objects. After ruling out various other explanations (e.g., that adults model object words more often than relational words), she argued that this discrepancy reflects differences in the cognitive "naturalness" of the corresponding concepts: object concepts are more "given", whereas relational concepts are more imposed by the structure of language and so require additional time to be constructed. Schlesinger (1977) also rejected strong cognitive determinism and argued on theoretical grounds for an interaction in early language acquisition between children's own concepts and the semantic categories modeled in the input language. And Bowerman (1978a) and Gopnik (1980) proposed that children at the single-word-utterance stage generalize words to novel referents on the basis of not only their nonlinguistic concepts but also their observations of regularities across the situations in which adults use the words.

Existing cross-linguistic studies do not show which is more important in very young children's acquisition of spatial language: nonlinguistic spatial knowledge or the semantic organization of the input language. By age 3, English- and German-speaking children differ strikingly from Spanish- and Hebrew-speaking children in how they express spatial information in a story-telling task (Berman \& Slobin, 1987). And 4- to 6-year-old children learning Warlpiri, an Australian language, differ from children learning English in the meanings they associate with spatial terms (Bavin, 1990). But it is not clear whether language specificity is present from the outset, as Gentner (1982) would predict, or emerges only gradually with divergence from a shared starting point, in line with Slobin (1985).

In this paper, we try to disentangle nonlinguistic spatial cognition from the structure of the linguistic input by comparing children acquiring English and Korean. We first contrast the way motion is lexicalized in the two languages, and then examine spontaneous speech from the period of one-word utterances and early word combinations.

\section{The lexicalization of motion events in English and Korean}

\section{Semantic components of a motion event}

In Talmy's analysis of how languages express motion, a "motion event" is defined as "a situation containing movement of an entity or maintenance of an entity at a stationary location" (1985, p. 60). By "movement" is meant a "directed" or "translative" motion that results in a change of location. By "location" is meant 
either a static situation or a "contained" motion that results in no overall change of location (e.g., jumping up and down, walking around in place). In this paper we focus on movement, along with a limited-although developmentally important - set of "contained" events, posture changes.

According to Talmy, a (dynamic) motion event has four basic components:

Motion: Presence of motion.

Figure: The moving object.

Ground: The reference-point object with respect to which the Figure moves.

Path: The course followed by the Figure with respect to the Ground.

These components can be identified in a straightforward way in the following English sentence:

(1) John went into the room .

[Figure] [Motion] [Path] [Ground]

A motion event can also have a "Manner" or a "Cause", which are analyzed as distinct external events. To this collection we will add "Deixis" (e.g., motion towards the speaker vs. away from the speaker), which seems to play a role in the lexicalization of motion events that is comparable to that of Manner or Cause (see DeLancey, 1985). ${ }^{1}$

According to Talmy, there are fundamental typological differences among languages in how a motion event is characteristically expressed in a sentence. In particular, he describes three patterns for what components are expressed by the main verb root and what is expressed by additional elements. We will be concerned with two of these: lexicalization or "conflation" in the main verb of Motion with either Manner or Cause, with path expressed separately, and conflation in the main verb of Motion with Path, with Manner or Cause expressed separately. (In the third, less common pattern, the main verb expresses Motion plus information about the Figure, with both Path and Manner or Cause expressed separately.)

\section{English: Conflation of Motion with Manner or Cause}

In English, as in most Indo-European languages and Chinese, Motion is characteristically conflated with Manner or Cause, and Path is expressed separately by

\footnotetext{
'Talmy (1985, p. 126) apparently regards Deixis (which he terms "Direction") as closely related to path in his analysis of the components of a motion event, and Aske (1989) treats it as a kind of Path. However, Deixis often patterns differently from other kinds of Paths in the way it is lexicalized (e.g., many languages express Deixis in main verbs like come and go cven though they do not typically express other kinds of Paths in the verb system), so we distinguish it in this paper.
} 
prepositions or particles (Talmy, 1975, 1985). The combination [Motion + Manner], for example, is found in The rock SLID/ROLLED/BOUNCED down (the hill), John WALKED/SKIPPED/RAN into the room, and John SLID/ ROLLED/BOUNCED the keg into the storeroom. The combination [Motion + Cause] is seen in The wind BLEW the napkin off the table and John PUSHED/ THREW/KICKED the keg into the storeroom. The combination [Motion + Deixis] is also found in English, as in John CAME/WENT into the room and John TOOK/BROUGHT the keg into the storeroom. ${ }^{2}$

As these sentences illustrate, English uses the same verb conflations in both intransitive sentences expressing spontaneous motions and transitive sentences expressing motions caused by an agent. In addition, it marks Path in the same way in sentences of both types, using prepositions and particles like in(to), out (of), on(to), off, up, down, and away. It also applies individual Path markers to a broad range of events within the domains of spontaneous and caused motion. For example, (put) on is used for the placement of clothing or other items onto all parts of the body, as well as for actions like putting a cup on a table, a lid on a jar, and a cap on a pen. Similarly, up and down are used not only for overall changes in the Figure's location (e.g., go up, run down) but also with posture verbs to indicate "in place" changes in the Figure's alignment or height with respect to the vertical axis, for cxample: She suddenly SAT UP (from a lying posture)/SAT DOWN (from a standing posture); she $L A Y D O W N$ (to take a nap); He STOOD UP (and left the room). (Posture verbs plus up or down also sometimes express static postures, e.g., he SAT DOWN all during the concert; see Talmy, 1985).

\section{Korean: Mixed conflation pattern}

In the second class of languages in Talmy's typology, which includes Romance, Semitic, and Polynesian, Motion is characteristically conflated with Path in the main verb, and Manner or Cause is expressed separately with an adverbial. Spanish examples with [Motion + Path] verbs include La botella ENTRÓ a la cueva (flotando) "The bottle MOVED-IN to the cave (floating)" and La botella $S A L I O ́$ de la cueva (flotando) "The bottle MOVED-OUT from the cave

\footnotetext{
${ }^{2}$ All transitive verbs that express caused movement incorporate a causative meaning. This inherent causativity is distinct from the component "Cause" in Talmy's analysis. For example, although bring and take are inherently causative, they do not specify an independent event such as kicking or pushing that makes the Figure move, so they are not analyzed as conflations of Motion with Cause. Conversely, although intransitive blow is not inherently causative (cf. the wind blew), it can express the conflation [Motion + Cause], as in The napkin blew off the table (=the napkin moved off the table, from the wind blowing on it). The conflation of Motion with Cause in intransitive sentences is somewhat restricted in English and will not concern us further; this allows us to use the term "intransitive" to refer to constructions that express spontaneous motion by the Figure.
} 
(floating)"; compare also SUBIR "move-up", BAJAR "move-down", and PASAR "move-past/through". Transitive Spanish verbs of the same type include MFTER "put in", PONFR "put on", JUJNAR "put together" and SEPARAR "take apart" (Talmy, 1985).

Korean presents a mixed picture. In transitive clauses for caused motion, it conflates Motion with Path, like Spanish. But in intransitive clauses for spontaneous motion, it encodes Motion, Path and (optionally) Manner or Cause with separate constituents, a pattern not described by Talmy. In clauses of both types, Korean expresses most Path information with verbs; it lacks a system of morphemes dedicated to Path marking like the English spatial prepositions and particles. However, it does have three locative case endings, EY "at, to", -LO "toward", and -EYSE "from", which, when suffixed to a Ground nominal, function like the Spanish prepositions $a$ "to" and de "from" in the examples above.

The basic word order of Korean is subject-object-verb. The verb phrase contains one or more "full" verbs; that is, verbs that can occur as the main verb or alone as a complete utterance (e.g., KA "go", imperative). The final verb of a sentence, which may be either a "full" verb or an auxiliary, bcars all the inflectional suffixes such as tense (Lee, 1989). A pre-final verb is linked to the final verb by a "connecting" suffix such as $-E$ or $-A$; the verbs together form a so-called compound verb.

\section{Spontaneous motion}

In expressions of spontaneous motion, the main (rightmost) verb is usually KATA "go" or OTA "come", in which motion is conflated with Deixis." This verb is preceded by a Path verb, which in turn may be preceded by a Manner verb. The pattern is thus [Manner] [Path] [Motion + Deixis], as illustrated in (2):

(2) John-i pang-ey (ttwui-e) tul-e o-ass-ta.

J.-SUBJ ${ }^{4}$ room-LOC (run-CONN) enter-CONN come-PST-DECL

[Figure] [Ground] ([Manner]) [Path] [Motion + Deixis]

"John came in(to) the room (running)."

\footnotetext{
"This verb can also be TANITA, which means "go and come repeatedly". However, TANITA does not combine with all Path verbs, and so is not as productive as the deictic verbs KATA "go" and OTA "come".

${ }^{4}$ The following abbreviations are used:
}

SUBJ - Subject marker

OBJ - Object marker

LOC - Locative marker

CONN - Connecting suffix

PST - Past tense marker

DECL - Declarative ending

CAUS - Causative suffix 
Table 1. Lexicalization of spontaneous changes of location in Korean

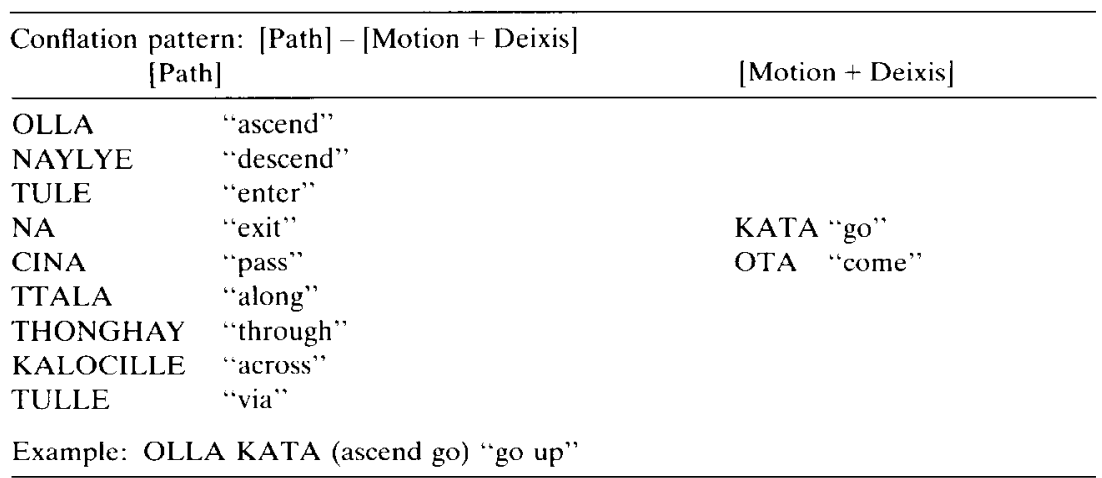

In this example, JOHN is the Figure, and PANG "room" is the Ground. The locative suffix -EY "to, at" on PANG indicates only that PANG represents the goal or location of the event specified by the verb. The fact that John changed his location is specified by the rightmost verb, O- "come". John's path with respect to the Ground is specified by the verb before O-: TUL- "enter". John's Manner of motion is specified by TTWUI- "run". Path verbs in addition to TUL- include NA- "exit", OLL- "ascend", and NAYLY- "descend"; a complete list is given in Table 1.

We translate intransitive Korean Path verbs with words like "enter" and "exit" instead of "in" and "out" to emphasize that they are verbs. But these translations are somewhat misleading, since they suggest that the verbs inherently conflate Motion with Path. In fact, the sense of motion in sentences like (2) comes primarily from the final verb, KATA "go" or OTA "come". If a Path verb is combined with ISSTA "be located" instead, it expresses static location. Path verbs can also be used as the main (rightmost) verb, in which case they express motion in a rather abstract, holistic way. ${ }^{5}$

\footnotetext{
"For example, in (1) below, TUL- "enter" is used with ISSTA "be located" to convey the static situation of the Figure. Similarly, in (2), OLL- "ascend" is the main verb. This sentence conveys the event of John's climbing the mountain as a whole; the fact that he had to move is backgrounded and not central to the meaning. In contrast, the sentence in (3), with the deictic verb KATA "go", expresses John's dynamic motion in climbing the mountain.

(1) cui-ka sangca-ey tul-e iss-ta.

mouse-SUBJ box-LOC enter-CONN be-DECL

"The mouse is in the box."

(2) John-i san-ey oll-ass-ta.

John-SUBJ mountain-LOC ascend-PST-DECL

"John climbed the mountain."

(3) John-i san-ey olla ka-ss-ta.

John-SUBJ mountain-LOC ascend go-PST-DECL

"John went up (onto) the mountain."
} 
As noted earlier, the English Path particles up and down are used to express not only changes of location (with verbs like go and run), but also changes of posture (with verbs like sit, stand, and lie). Korean, in contrast, expresses posture changes with monomorphemic verbs, for example, ANCTA "sit down", NWUPTA "lie down", (ILE)SETA "stand up", ILENATA" "get up", KKWULTA "kneel down", KITAYTA "lean against". When these posture verbs are preceded by the Path verbs OLL- "ascend" and NAYLY- "descend", the resulting phrase does not have the same meaning as English stand up, sit down, etc.: it specifies that the Figure first gets up onto a higher surface or down onto a lower surface, and then assumes the indicated posture.

\section{Caused motion}

While spontancous motion is encoded in "exploded" fashion in Korean, in that Motion, Path, and Manner are specified by separate words, caused motion is expressed quite compactly with inherently causative transitive verbs that conflate [Motion + Path]. Table 2 lists some frequent transitive Path verbs.

Recall that, in English, Path is marked the same way whether a motion is spontaneous or caused (cf. The ball rolled INTO/OUT OF the box vs. John rolled the ball INTO/OUT OF the box). For English speakers, it is so natural to think of these two Path meanings as "the same" that it is hardly worth remarking on. In Korean, however, Path is usually marked by different forms in the two cases; note that the only verb roots that appear in both Table 1 (intransitive Path verbs for spontaneous motion) and Table 2 (transitive Path verbs for caused motion) are OLL- "ascend" and NAYLY- "descend"? (These roots are inherently intransitive; the transitive forms are derived by adding the causative suffix -I.)

Not only are Path forms different for spontaneous and caused motion, but so are most of their meanings. Consider notions of joining and separation (bringing an object into or out of contact with another), which are typically expressed in English with phrases like put in/on/together and take out/off/apart. These are encoded in Korean with a variety of verbs, as shown in Table 2." KKITA (glossable loosely as "fit", but used much more widely than English $f(t)$ is indifferent to whether the Figure goes into, onto, over, or together with the Ground, as long as it leads to a tight fit/three-dimensional meshing; hence, it is routinely used to express putting earplugs INTO ears and a cassette INTO a cassette case, one Lego piece ONTO or TOGETHER with another, and the top

\footnotetext{
"The morpheme ILE may have the meaning "ascend" but it occurs only with these two posture verbs, optionally with SETA "stand up", and obligatorily in ILENATA "get up".

"The two verbs TUL- "enter" and NA "exit" can also take the causative suffix. However, their causative forms are not productive spatial verbs hecause they cannot stand alone, and when they combine with other verbs they have idiomatic senses, e.g., SON-UL NA-I MILTA "hand-OBJ exit-CAUS push" (=put hand out to shake hands or receive something).

"If a Ground nominal is included in the sentenee, it is marked with the suffix -EY "at, to" or -EYSE "from", as appropriate.
} 
Table 2. Korean transitive verbs for caused motion

\begin{tabular}{|c|c|}
\hline Verb & Meaning (Examples) \\
\hline \multicolumn{2}{|c|}{ Cause to ascend/descend } \\
\hline OLLITA & $\begin{array}{l}\text { Cause something to ascend. } \\
\text { (Move a poster upward on the wall) }\end{array}$ \\
\hline NAYLITA & $\begin{array}{l}\text { Cause something to descend. } \\
\text { (Move a poster downward on the wall) }\end{array}$ \\
\hline \multicolumn{2}{|l|}{ Join/separate } \\
\hline $\begin{array}{l}\text { KKITA } \\
\text { /PPAYTA }\end{array}$ & $\begin{array}{l}\text { "Fit"/"unfit" one three-dimensional object to/from another. } \\
\text { (Lego pieces, ear plugs-ears, cassette-cassette case, top-pen, } \\
\text { ring-finger) }\end{array}$ \\
\hline $\begin{array}{l}\text { NEHTA } \\
\text { /KKENAYTA }\end{array}$ & $\begin{array}{l}\text { Put/take things in/out of a loose container. } \\
\text { (wallet handbag, ball box, furniture room) }\end{array}$ \\
\hline $\begin{array}{l}\text { PWUTHITA } \\
\text { /TTEYTA }\end{array}$ & $\begin{array}{l}\text { Join/separate a flat surface to/from another flat surface. } \\
\text { (sticker-book, poster-wall, two table sides) }\end{array}$ \\
\hline KKOCTA & $\begin{array}{l}\text { Put a solid object elongated in one dimension into/onto a base. } \\
\text { (flower-vase, book-shelf, dart-board, hairpin-hair) } \\
\text { /Separation: PPAYTA when the base holds the figure tightly, } \\
\text { KKENAYTA when it holds it loosely }\end{array}$ \\
\hline $\begin{array}{l}\text { TAMTA } \\
\text { /KKENAYTA }\end{array}$ & $\begin{array}{l}\text { Put/take multiple objects in/out of a container that one can carry. } \\
\text { (fruits-basket, candies-bowl, toys-box) }\end{array}$ \\
\hline SITTA & $\begin{array}{l}\text { Load something into/onto a vehicle. } \\
\text { (hay-truck, package-car, car-boat) } \\
\text { / Scparation: NALUTA ("move an object from onc place to another") } \\
\text { when the object is moved to another place, but NOHTA (see below) } \\
\text { when the object is put down on the ground }\end{array}$ \\
\hline $\begin{array}{l}\text { PWUSTA } \\
\text { /PHWUTA }\end{array}$ & $\begin{array}{l}\text { Pour liquid (or a large quantity of tiny objects) into/out of a container } \\
\text { (milk-cup, sand-pail) }\end{array}$ \\
\hline NOHTA & $\begin{array}{l}\text { Put something loosely on a surface. } \\
\text { (pen-table, chair-floor) } \\
\text { / Separation: TULTA for focusing on taking the object into the hand, } \\
\text { CIPTA for focusing on picking it up. }\end{array}$ \\
\hline KKATA & $\begin{array}{l}\text { Take off a covering layer or wrapper. } \\
\text { (shell-nuts, peel-banana, wrapper-candy) } \\
\text { Joining: SSATA for wrapping an object tightly. }\end{array}$ \\
\hline KKAKTA & $\begin{array}{l}\text { Take off a covering layer with knife. } \\
\text { (skin-apple, planing a board, sharpening a pencil) }\end{array}$ \\
\hline \multicolumn{2}{|c|}{ Put clothing item onto one's own body part } \\
\hline IPTA & Trunk of body (dress, shirt, pants) \\
\hline SSUTA & Head (hat, umbrella) \\
\hline SINTA & Feet, legs (socks, shoes) \\
\hline $\begin{array}{l}\text { CHATA } \\
\text { (PESTA is the ro }\end{array}$ & $\begin{array}{l}\text { Waist, wrist (belt, watch, diaper) } \\
\text { everse of all of these) }\end{array}$ \\
\hline \multicolumn{2}{|c|}{ Put something onto/into one's own body part in order to support or carry it } \\
\hline ANTA & Arms (a person, an object, e.g., baby, package) \\
\hline EPTA & Back (a person, e.g., a baby or child on mother's back) \\
\hline CITA & Back (an object, if not also supported by shoulder) \\
\hline MEYTA & Shoulder (an object hanging, e.g., backpack, bag over shoulder) \\
\hline ITA & Head (an object, e.g., a pot) \\
\hline TULTA & Hand (an object, e.g., briefcase, suitcase) \\
\hline MWULTA & Mouth (an object, e.g., a cigarette) \\
\hline
\end{tabular}


of a pen ONTO (="OVER") the pen. The reversal of these actions is specified by PPAYTA "unfit". Because of the KKITA/PPAYTA Path category, Korean speakers must distinguish actions of putting in/on/together that result in a fitting relationship (KKITA) from those that result in loose containment (NEHTA) or surface contact (NOHTA, PWUTHITA); similarly, they must distinguish "taking out" of tight versus loose containment (PPAYTA vs. KKENAYTA) and "taking off" or removal from attached versus loose surface contact (PPAYTA or TTEYTA vs. CIPTA). These groupings and distinctions in Path meanings are not made in expressions for spontaneous movements into or out of a container, onto or off a surface, etc., since KKITA and PPAYTA do not have intransitive counterparts.

Transitive Path verbs of joining and separation also contrast with intransitive Path verbs in that they incorporate aspects of Figure and Ground as well as Path. For example, different verbs are used for solid versus liquid Figures, for threedimensional versus flat versus elongated Figures, and for Ground objects that are conventionally used for carrying things versus vehicles versus other kinds of Grounds (see Table 2). Fine distinctions are made when the Ground is part of the human body: there are different verbs for putting clothing onto different body parts, and also for putting people or objects into/onto the arms, back, shoulder, head, mouth, and hand for purposes of support or carrying. Acts of putting a Figure onto the back are distinguished according to whether the Figure is animate or inanimate.

In Korean, expressions for caused motion also differ from those for spontancous motion with respect to Deixis. Recall that intransitive expressions of spontaneous motion typically have as main verbs KATA "go" or OTA "come", which conflate Motion with Deixis. But for caused motion, Korean has no deictic transitive verbs comparable to English take and bring. Self-initiated changes of location by animate beings are consistently encoded with intransitive deictic verbs. When someone "takes" or "brings" something while moving, this can be expressed by combining KACY-E "have" with KATA "go" or OTA "come"; for example, John took/brought a book to the library is rendered as JOHN-I CHAYK-UL TOSEKWAN-EY KACY-E KA-/O-ASS-TA "John-SUBJ bookOBJ library-LOC have-CONN go-/come-PST-DECL" (=John went/came to the library having a book).

In transitive clauses, just as in intransitive clauses, Manner can be expressed with a verb preceding the Path verb, for example, TOLLY-E PPAYTA (turn "unfit"): "take Figure from its tightly fitting ground by turning it; twist out/off/ apart". The pre-final verb can also express Cause, for example, MIL-E NEHTA (push put-in): "put something in a container by pushing it; push in". "However,

\footnotetext{
"Certain Path-conflating transitive verbs can also be used as Manner verbs in combination with a second Path-conflating transitive verb, because they express some Manner information in addition to Path information. For example, KKITA "fit" and PPAYTA "unfit" suggest that the action requires a bit of force; hence, one can say KKI-E NEHTA (fit put-in) to express shoving a block of a certain shape through a matching hole in a child's shape-fitting box so that the block falls down inside.
} 
these combinations are less frequent than constructions like twist/pull/cut/roll off and push/throw/kick/slide in in English. This is because the two languages differ in what information must be expressed and what can be left to inference.

In English it is often obligatory to spell out Path rather completely, even when it can be readily inferred from context. If we heard "John threw his keys TO his desk/TO the drawer", we could reasonably suppose that the keys ended up ON the desk or IN the drawer. Still, these sentences sound odd: on and $i n$ are needed. Even when it is grammatical to specify Path less completely, fuller information is often given, especially in everyday speech; compare John took his keys FROM his desk/FROM the drawer (a bit formal or bookish) with John took his keys OFF his desk/OUT of the drawer (completely colloquial). In Korean, in contrast, a Path verb can often be omitted if a transitive verb' expressing the Manner or Cause of the motion is supplied. As long as the Ground is specified and the relationship between Figure and Ground can be easily inferred, locative case endings such as -EY "to, at" or -EYSE "from" on the Ground nominal are sufficient, and a Path verb often sounds redundant."

\section{Summary of the lexicalization of motion events in English and Korean}

To summarize, English uses the same verb conflation patterns in both intransitive clauses expressing spontaneous motion and transitive clauses expressing caused motion, and it encodes Path separately with the same Path markers (particles and prepositions) whether the clause is transitive or intransitive. Korean, in contrast, uses different lexicalization patterns for spontaneous motion and caused motion, and most of its Path markers (verbs) in the two cases are distinct. An overview of these patterns is given in Table 3. In addition, many Korean Path verbs have a

\footnotetext{
${ }^{10}$ For example, in (1) below, the Ground "desk" is specified with the locative marker (-ey), and the main verb is the Cause verb. In (2), both Cause (TFNCY-) and Path (NOH-) verbs are present in addition to the Ground; to Korean speakers this seems redundant.
}

(1) John-i yelswey-lul chayksang-ey TENCY-ess-ta. John-SUBJ key-OBJ desk-LOC throw-PST-DECL

"John threw keys TO desk."

(2) ? John-i yelswey-lul chayksang-ey TFNCY-e NOH-ass-ta. John-SUBJ key-OBJ desk-LOC throw-CONN put-on-PST-DECL

"John threw keys ONTO desk."

Fuller Path information can be supplied in sentences like (1) by a finer specification of the Ground object; for example:

(3) John-i yelswey-lul chayksang-wui-ey IENCY-ess-ta. John-SUBJ key-OBJ desk-top-LOC throw-PST-DECL

"John threw keys TO desktop."

(4) John-i yelswey-lul selhap-an-ey TENCY-ess-ta. John-SUBJ key-OBJ drawer-inside-LOC throw-PST-DECL

"John threw keys TO inside of drawer." 
Table 3. Comparison of English and Korean conflation patterns for motion events

\begin{tabular}{|c|c|c|c|c|}
\hline \multicolumn{2}{|l|}{ English } & \multicolumn{3}{|l|}{ Korcan } \\
\hline \multicolumn{5}{|c|}{ Spontaneous motion } \\
\hline Verb & Particle & Verb & Verb & Verb \\
\hline [Motion + Manner] & [Path] & [Manner] & [Path] & [Motion + Deixis] \\
\hline \multicolumn{5}{|c|}{ Caused motion } \\
\hline Verb & Particle & Verb & Verb & \\
\hline [Mution + Manner] & [Path] & [Manner] & [Mot & Path + Ground]" \\
\hline [Motion + Cause] & & [Cause] & & \\
\hline [Motion + Deixis] & & & & \\
\hline
\end{tabular}

"These verbs are inherently transitive and causative.

narrower range of uses than the English Path markers that translate them. For example, OLL- "ascend" and NAYLY- "descend" are used only for changes of location and not posture, while English uses up and down for both. Similarly, Korean uses different verbs for putting clothing onto different parts of the body and for placing objects onto other surfaces, while English uses on across this whole range. ${ }^{11}$

\footnotetext{
${ }^{11}$ In addition to verbs conforming to the characteristic conflation pattern of English described by Talmy $(1975,1985)$, English has a number of intransitive and transitive Path-conflating verbs. Many of these, including enter, exit, ascend, descend, insert, extract, join, and separate, are borrowings from Romance. In Romance they represent the basic pattern, whereas in English they belong to a more formal register than their native counterparts go in/out/up/down, put in/together, take out/apart. A few path verbs, such as fall, rise, and raise, are native to English. Notions of Motion and Path and sometimes Figure or Ground also seem to lurk in the more complex meanings of a variety of other verbs such as pluck, stuff, jam, peel, load, fit, and unwrap. In light of such verbs. Steve Pinker (personal communication) has suggested to us that the differences between English and Korean might be "more in the number and frequency of verbs used than in some major typological parameter of the entire language". But we believe that the differences are more fundamantal. In Korean, Path meanings are expressed almost exclusively by Path verbs (only "at/to" and "from" are expressed separately, and only if the Ground object is mentioned). In English, however, most native Path verbs may or even must combine with a separate preposition or particle that either marks the incorporated Path meaning redundantly or specifies it more precisely; compare fall $D O W N$, rise/raise UP, stuff/jam $X$ INTO $Y$, pluck $X$ OFF/OUT of $Y$, peel $X$ OFF $Y / X$ and $Y$ APART, load $X$ ONTO/INTO $Y$, fit $X$ INTO/ONTO/TOGETHER with $Y$. This is true even of some of the Romance borrowings, e.g., insert $X$ INTO $Y$, not simply ...TO $Y$. Candidate Path verbs may be absorbed into the basic English pattern of marking Path separately hecause they often incorporate elements of Manner as well as Path and so can be treated as [Motion + Manner] conflations; for example fall means something like "to go down in an uncontrolled manner", insert suggests "to put in in a controlled way" (c.g., because the space is small), stuff suggests the use of force, and peel specifies a particular manner in which two surfaces separate.
} 


\section{Development of motion expressions in English and Korean}

Children learning English and Korean must, then, master different systems for lexicalizing motion events. How do they approach this task? The English data we use to investigate this question come from Bowerman's diary records of her two daughters, $\mathrm{C}$ and $\mathrm{E}$. Data collection began when the children were about 1 year old and cover the period of one-word utterances and early word combination in rich detail. Aspects of the expression of motion in these records have been discussed in Bowerman (1976, 1978a, 1978b, 1980). The data can be compared with information given in a number of studies of children learning English, including Bloom (1973), Farwell (1977), Gopnik (1980), Greenfield and Smith (1976), McCune-Nicolich (1981), and Tomasello (1987).

Our main set of Korean data was collected longitudinally by Choi, who visited four children in their homes every three to four weeks from age 14 to 24-28 months (group I). At each session, she and the mother played with the child for 60-90 minutes. All sessions were video-taped and transcribed. Choi also elicited mothers' reports on their children's uses of spatial expressions. These data are supplemented by data collected from four other Korean children every two to four weeks from 19-20 months to 25-34 months (group II). ${ }^{12}$

Early in language development, most references to action take place in the immediate context of the action. In this study we consider only utterances produced while a motion event was taking place, just after it had occurred, or just before it occurred as a statement of intention, desire, or expectation. Both the English- and Korean-speaking children began to use words to encode motion in such situations in the same age range - around 14-16 months.

The motion events referred to by the two sets of children were remarkably similar. For example, they commented on their own changes of posture or location, such as sitting down, standing up, or climbing up onto chairs or laps; they appealed to adults for help in changing location or to go outside; they asked to be picked up or carried; and they referred to donning and doffing clothing and to object manipulations of many kinds, for example, putting things into a bag and taking them out and putting Lego pieces or Popbeads together and taking them apart. Some examples are shown in Table 4. These similar preoccupations - also shown by Dromi's (1987) Hebrew-speaking daughter at the one-word stage - are apparently driven by shared aspects of children's general cognitive development, including what they are interested in talking about (Gopnik \& Choi, 1990; Gopnik \& Meltzoff, 1986).

Underlying the impression of similarity between the two sets of children there are important differences. We look first at the children learning English and then

\footnotetext{
${ }^{12}$ Pat Clancy collected the data from two of these children, and Young-Joo Kim from one; the fourth was studied by Choi. We would like to thank Clancy and Kim for their generous permission to use their data
} 
Table 4. Words produced in similar contexts by learners of English and Korean between 14 and 21 months

\begin{tabular}{lll}
\hline Contcxt & English & Korean" \\
\hline Wanting to go outside & out & pakk-ey "outside-LOC" \\
Asking M to pick her up & up & $\begin{array}{l}\text { anta "pick up and hold in arms" } \\
\text { ancta "sit down" } \\
\text { ilting down }\end{array}$ \\
$\begin{array}{l}\text { Asking M to get up } \\
\text { in the morning }\end{array}$ & up & kkita "fit" \\
Joining two Lego pieces & on & ppayta "unfit" \\
Separating Popbeads & off & ipta "put clothes on trunk" \\
Putting coat on & on & nehta "put in loosely" \\
Putting toys in container & in & kkita "fit" \\
Putting a small object & in & \\
into a hole or a crack & &
\end{tabular}

"The verb ending -TA on all but the first example is the citation form. Endings actually produced by the children include various modals like - $\mathrm{E}$ (or -A) for requests or assertions (e.g., an-a for an-ta "pick up and hold in arms" and anc-a for anc-ta "sit down"), and -TA for certain types of assertions (Choi, 1991).

at the children learning Korean, focusing on spontaneous versus caused motion, motion "up" and "down", and how Path morphemes combined with verbs. ${ }^{13}$

\section{English}

\section{Words used for motion events}

It is well known that words like down, up, in, out, on, off, back, and away play a central role in the early expression of motion by children learning English, first appearing as single-word utterances and later figuring in early word combinations (Bloom, 1973; Farwell, 1977; Gopnik, 1980, Greenfield \& Smith, 1976; Gruendel, 1977a; McCune-Nicolich, 1981; Miller \& Ervin, 1964; Tomasello, 1987). This is true also for our two diary subjects, C and E (Bowerman, 1976, 1978a, 1980). In adult speech, these words often appear as verb particles in sentence-final position with heavy stress, which may make them especially salient to children (Brown, 1973; Slobin, 1973; Tomasello, 1987). Many of them also serve as prepositions in adult English, and can express static location, as in The book is IN the bookcase. However, children at first use them primarily or exclusively for motion. $C$ and $E$ began to use them for static location in the second half of the second year; for

\footnotetext{
${ }^{13}$ See Bowerman (1989) and Bowerman and Choi (in preparation) on the expression of caused motion, especially how children catcgorizc manipulations like putting things into/onto/together with other things and taking them out/off/apart.
} 
example, in produced while peeking into the bag in which a hamburger had just arrived in a restaurant ( $\mathrm{E}, 19$ months). Other words that $\mathrm{C}$ and $\mathrm{E}$ used for motion events between 14 and 18 months include go, come, sit, walk, run, jump, ride, fall, push, pull, and throw.

\section{Spontaneous versus caused motion}

Table 5 shows the emergence of Path particles and verbs for spontaneous versus caused motion in C's and E's speech. Utterances are classified according to

Table 5. Early words for spontaneous and caused motion events in C's and E's speech

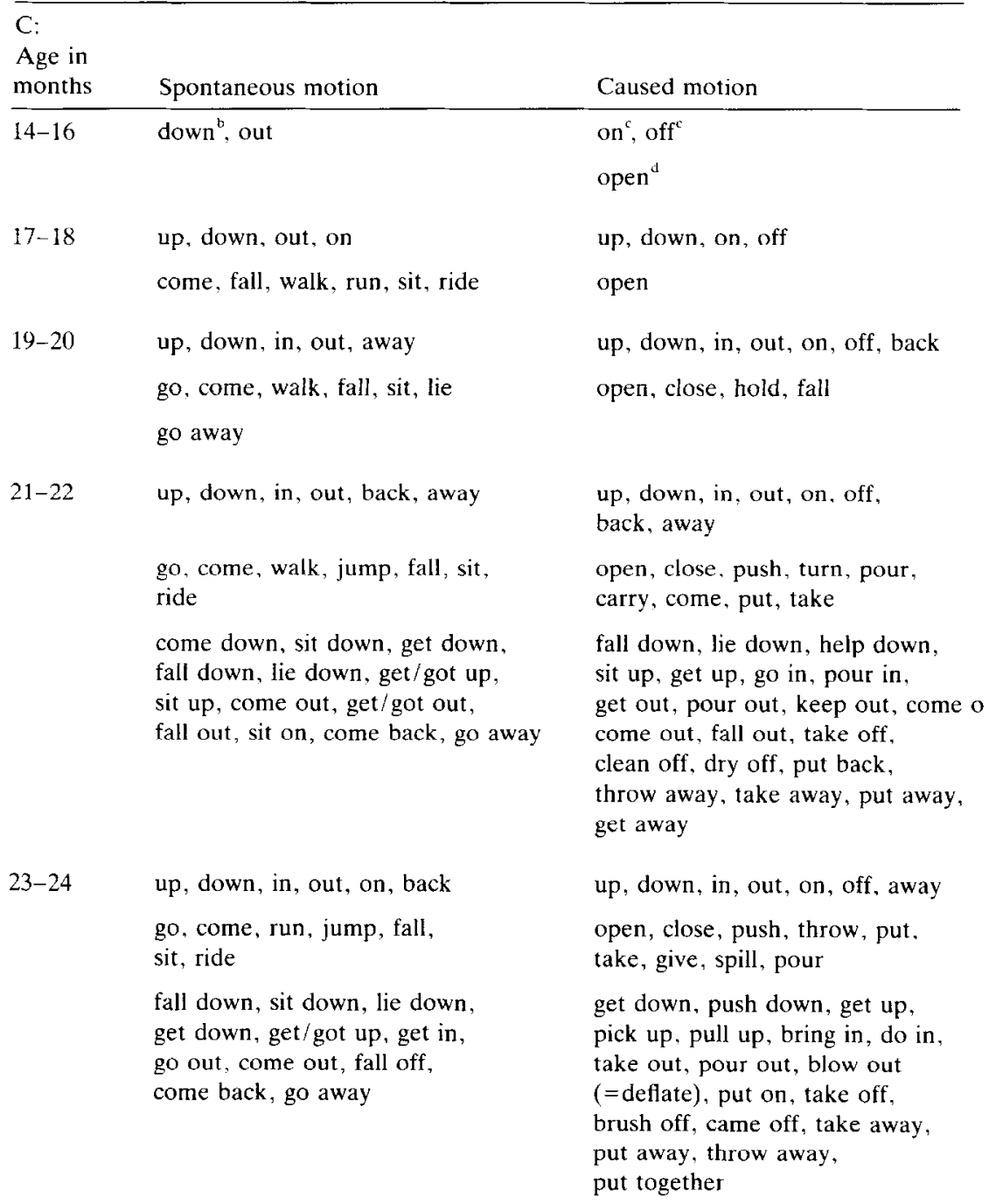


Table 5 continued.

\begin{tabular}{|c|c|c|}
\hline $\begin{array}{l}\text { E: } \\
\text { Age in } \\
\text { months }\end{array}$ & Spontaneous motion & Caused motion \\
\hline \multirow[t]{2}{*}{$14-16$} & up. down. out & down. off. back \\
\hline & go, come & open, close, push, pull, throw \\
\hline \multirow[t]{2}{*}{$17-18$} & out $^{\mathrm{c}}$ & up, on, off, in, back \\
\hline & go, walk, jump, fall, sit & $\begin{array}{l}\text { open, close, push, pull, throw, } \\
\text { sit, fall }\end{array}$ \\
\hline \multirow[t]{3}{*}{$19-20$} & $\begin{array}{l}\text { up, down, in, out, on, off, back, } \\
\text { away }\end{array}$ & $\begin{array}{l}\text { up, down, in, out, on, off, back, } \\
\text { away }\end{array}$ \\
\hline & go, come, walk, run, fall, ride & $\begin{array}{l}\text { open, close, push, pull, spill, } \\
\text { pour, kick, throw, take, come, } \\
\text { carry, fit }\end{array}$ \\
\hline & $\begin{array}{l}\text { come up, get up, stand up, step up, } \\
\text { sit down, lie down, fall down, } \\
\text { run down, come in, come out, } \\
\text { get out, going on, come/came off, } \\
\text { get off, come back, get away }\end{array}$ & $\begin{array}{l}\text { stand up, get down, pour in, } \\
\text { close in, came on, came off, } \\
\text { take off, fall off, get off, } \\
\text { throw away }\end{array}$ \\
\hline \multirow[t]{3}{*}{$21-22$} & $\begin{array}{l}\text { up, down, in, out, on. off, back. } \\
\text { away }\end{array}$ & $\begin{array}{l}\text { up, down, in, out, on, off, back, } \\
\text { away }\end{array}$ \\
\hline & $\begin{array}{l}\text { go, come, run, walk, fall, climb, } \\
\text { ride }\end{array}$ & $\begin{array}{l}\text { open, close, push, pull, take, } \\
\text { put, bring, give, turn, kick, } \\
\text { carry, fall, spill, pour }\end{array}$ \\
\hline & $\begin{array}{l}\text { get up, stand up, came up, } \\
\text { reach up, play up, go up and down, } \\
\text { come down, fall down, get down, } \\
\text { lie down, come in, get in, sit in, } \\
\text { come out, fall out, get out, } \\
\text { stick out, blow out (i.e., go out of } \\
\text { window), get on, come/came off, } \\
\text { come/came back, going away, } \\
\text { going around }\end{array}$ & $\begin{array}{l}\text { carry up, get up, pull up, put } \\
\text { down, push down, pull down, } \\
\text { pour down, put in, get in, push in, } \\
\text { fit in, pour in, dip in, take } \\
\text { out, pull out, get out, carry } \\
\text { out, put on, get on, take on, } \\
\text { take off, get off, push off, } \\
\text { came off, fell off, put back, } \\
\text { give back, throw away. }\end{array}$ \\
\hline
\end{tabular}

"Particles and verbs are listed only if they were produced spontaneously (i.c., not imitated) at least three times during the period shown, either in isolation or in combination with other words. All non-imitated verb + particle combinations are listed.

'Most uses of down in this period were for getting off a rocking horse. sometimes with an adult's help. One instance was for going downstairs.

"Until 18 months C pronounced both on and off as /a/ (final consonants in general were missing), so it is unclear whether she had two words or one.

'Although open and close are not used in adult English for caused motion (i.e.. change of location), the children often overextended them to contexts in which adults would say take offlout/apart or pul on/in/together (see Bowerman, 1978a).

${ }^{\mathrm{C}} \mathrm{E}$ often said $u p$ and down for static position in this period (e.g., up while looking at something high on a shelf.) 
whether the motion was (or would be, in the case of anticipated events) spontaneous, or required an agent's causal action. Most utterances classified under "spontaneous motion" were used for self-initiated motion by animate beings, usually the child herself (see Huttenlocher, Smiley, \& Charney, 1983). They also included uses of up and down for changes of location that the child initiated and was active in pursuing, even though she was helped by an adult, for example, up as the child clambered up on a chair with a boost. (Up or down as requests to be picked up or lifted down, or comments on these actions, were classified as caused motion.)

Utterances were classified under "caused motion" when they referred to a motion brought about by an external agent. When a child says "in" while putting a ball into a box, we cannot be certain whether she intends to refer to the agent's action ("put in"), or only to the motion of the Figure ("go in"). Adult English often allows the speaker to focus only on the Figure"s motion, leaving the agent out of perspective (Talmy, 1985), and children in the early period of word combining say both "put $X$ in" and "X goes in" (for example) in the context of caused motion (Bloom, Lightbown, \& Hood, 1975). Our classification thus uses the nonlinguistic context as a guide - imperfect in the case of caused motion - to the child's likely intentions.

In the age period 14-16 months, $\mathrm{C}$ and $\mathrm{E}$ produced only a few Path particles. All but one (E's down) were applied to either spontaneous motion or caused motion, but not both. In some cases this reflected the child's initial restriction of the form to specific contexts; for example, at first $\mathrm{C}$ said out only for going outdoors (spontaneous) and E said off only for removing clothing and other objects from the body (caused). In other cases, however, the child used the form quite productively within the limits of spontaneous or caused motion (see Bowerman, 1978a, 1980, on C's extensive use of on and off).

Over the next few months, however, the children used Path particles increasingly often for both spontaneous and caused motion. By 19-20 months, they used almost all Path particles in both ways, and for a wide variety of spontaneous and caused motion events. For example, they used on for sitting or standing on things and for putting on clothing of all kinds, attaching tops to pens and stickers to surfaces, and putting objects down on surfaces, and off for the reverse of these actions. They used in for going into houses, rooms, bathtubs, and the child seat of a shopping cart and for putting things into various containers (e.g., pieces into puzzles, noodles into bowl, riding toys into house), and out for the reverse of these actions (scc Gopnik, 1980, and Gopnik \& Meltzoff, 1986, for similar uses by other children). They used back for their own or another person's spontaneous return to an original location, for putting objects back where they were usually kept (e.g., watch on arm, books on shelf), and for rejoining parts of an object (e.g., top on pen, lid on bottle). Between 17 and 20 months they also used many 
of the particles for static spatial relations, for example, in when looking at a box with crackers in it or a picture of a bear in a helicopter.

Combining Path with Manner/Cause/Deictic verbs

By 19 months (E) and 21 months (C), the children began to combine Path particles with a variety of verbs specifying the Manner, Cause, or Deictic aspect of a motion event (see Table 5) (combinations with nouns naming the Figure started earlier). Many of the children's verb-particle combinations are also common in adult speech, but there is evidence that they understood the underlying combinatorial principle and were not simply imitating. First, they produced novel combinations such as "carry up" (picking up and righting a fallen-over stool; E, 21 months), "sit in" (after another child got into a bus and sat down; E, 21 months), "close in" (trying to stuff jack-in-the-box down into box and shut lid; E, 20 months), "catch in" (asking M to capture her between two boxes; E, 24 months), "do it in" (=put it in; C, 23 months), and "blow out" (a) holding hand out of open car window; E, 22 months; (b) asking F to deflate a beach ball; C, 24 months). Second, the particle and the verb in the children's combinations factored motion events appropriately into an independent Path and Motion; for example, out expressed a Figure's exit from containment regardless of whether the action was specified as fall, pour, or take, while the use of pull, push, fall, etc., was indifferent to whether the Path followed by the Figure was specified as up, down, in, out, on, off, or back.

\section{$D O W N$ and $U P$}

We will illustrate English-speaking children's use of Path morphemes more closely with down and up. These are typically among the first words used for motion events: one or both sometimes appear as early as 12-14 months (e.g., Farwell, 1977, Greenfield and Smith, 1976; Gruendel, 1977a; Nelson, 1974), and they are often present by 16 or 17 months (Bloom, 1973; Gopnik, 1980; Ingram, 1971; Tomasello, 1987). In E's speech, down appeared at 13 months and $u p$ at 16 months; in C's it was 16 and 17 months. Both children occasionally overextended down to "up" situations before learning up, an error also reported by Greenfield and Smith. In Table 6, we show representative uses in chronological order for each child.

Like many children reported in the literature, $\mathrm{C}$ and $\mathrm{E}$ at first said $u p$ and/or down primarily or exclusively for movements of their own bodies, either spontaneous (including assisted) or caused by an adult. But they soon became more flexible. Between 16 and 20 months, both children said up and down for their own and other people's spontaneous vertical motions, including both changes of location like falling and getting on or climbing off raised surfaces such as chairs, couches, riding toys, and laps, and changes of posture like sitting down, standing 
Table 6. Examples of DOWN and UP in C's and E's early speech

\begin{tabular}{|c|c|c|}
\hline & $\begin{array}{l}\text { Spontaneous motion } \\
\text { (age in months) }\end{array}$ & $\begin{array}{l}\text { Caused motion } \\
\text { (age in months) }\end{array}$ \\
\hline & \multicolumn{2}{|c|}{ DOWN } \\
\hline \multirow[t]{8}{*}{$\mathrm{C}:$} & $\begin{array}{l}\text { Wanting } M \text { to help her get } \\
\text { down from rocking horse (16) }\end{array}$ & \\
\hline & Climbing down from doll's & Pushing cat's head down (17) \\
\hline & & Taking cow down out of crib (17) \\
\hline & Sliding down off bed (18) & $\begin{array}{l}\text { Wanting } M \text { to take her out of } \\
\text { Roc-n-Spin chair (18) }\end{array}$ \\
\hline & Coming downstairs (18) & \\
\hline & $\begin{array}{l}\text { Climbing down out of } \\
\text { washtub (19) }\end{array}$ & $\begin{array}{l}\text { Wanting } M \text { to take her down from } \\
\text { dressing table (19) }\end{array}$ \\
\hline & $\begin{array}{l}\text { Watching squirrel come down } \\
\text { tree }(20)\end{array}$ & \\
\hline & Coming downstairs (21) & \\
\hline \multirow[t]{11}{*}{ E: } & $\begin{array}{l}\text { Trying to climb down off } \\
\text { counter (13) }\end{array}$ & $\begin{array}{l}\text { Wanting } M \text { to take } C \text { down from } \\
\text { chair (13) }\end{array}$ \\
\hline & $\begin{array}{l}\text { At top of slide wanting } \\
\text { to slide down (14) }\end{array}$ & $\begin{array}{l}\text { Asking } M \text { to take her down from } \\
\text { counter (14) }\end{array}$ \\
\hline & $\begin{array}{l}\text { Wanting } C \text { to come down from } \\
\text { counter (15) }\end{array}$ & \\
\hline & Asking $M$ to sit down (16) & Dumping an armload of yarn into \\
\hline & Sitting down in car (16) & her wagon (16) \\
\hline & Climbing down from chair (16) & Setting books on the floor (16) \\
\hline & & $\begin{array}{l}\text { Wanting to take chair down from } \\
\text { on table (16) }\end{array}$ \\
\hline & Asking $F$ to sit down (17) & $\begin{array}{l}\text { Wanting } M \text { to put beads down on } \\
\text { the floor (17) }\end{array}$ \\
\hline & & $\begin{array}{l}\text { Wanting } M \text { to put her cup down } \\
\text { on saucer }(18)\end{array}$ \\
\hline & $\begin{array}{l}\text { After getting from chair to } \\
\text { floor (19) }\end{array}$ & \\
\hline & $\begin{array}{l}\text { Getting down from high } \\
\text { chair }(20)\end{array}$ & $\begin{array}{l}\text { Wanting } M \text { to take cup down from } \\
\text { desk (20) }\end{array}$ \\
\hline & & \\
\hline \multirow[t]{7}{*}{$\mathrm{C}$ : } & Climbing up steps (17) & \\
\hline & $\begin{array}{l}\text { Wanting to get on upper } \\
\text { bunk bed }(18)\end{array}$ & $\begin{array}{l}\text { Trying to get her walker up onto } \\
\text { the couch (18) }\end{array}$ \\
\hline & $\begin{array}{l}\text { Wanting to climb on } \\
\text { counter (18) }\end{array}$ & \\
\hline & $\begin{array}{l}\text { Climbing onto the couch } \\
\text { (18) }\end{array}$ & \\
\hline & $\begin{array}{l}\text { Wanting to get into M's } \\
\text { lap (18) }\end{array}$ & \\
\hline & $\begin{array}{l}\text { Wanting } M \text { to stand up } \\
\text { by the crib (19) }\end{array}$ & \\
\hline & $\begin{array}{l}\text { Wanting } F \text { to get out of } \\
\text { bed (19) }\end{array}$ & \\
\hline
\end{tabular}


Table 6 continued.

\begin{tabular}{|c|c|c|}
\hline & $\begin{array}{l}\text { Spontaneous motion } \\
\text { (age in months) }\end{array}$ & $\begin{array}{l}\text { Caused motion } \\
\text { (age in months) }\end{array}$ \\
\hline & \multicolumn{2}{|c|}{ UP (continued) } \\
\hline \multirow[t]{3}{*}{$\mathrm{C}:$} & $\begin{array}{l}\text { Wanting } M \text { to get out of } \\
\text { bed }(20)\end{array}$ & $\begin{array}{l}\text { Picking up crayons from the } \\
\text { floor (21) }\end{array}$ \\
\hline & & $\begin{array}{l}\text { When somebody picks up a baby } \\
\text { (21) }\end{array}$ \\
\hline & & $\begin{array}{l}\text { Picking up a piggy bank and } \\
\text { taking it to a pile of } \\
\text { toys she's making ( } 21)\end{array}$ \\
\hline \multirow[t]{11}{*}{ E: } & Standing up in the car (16) & \\
\hline & Climbing up the slide (16) & \\
\hline & Standing up in her crib (16) & \\
\hline & Climbing up on her horse (16) & \\
\hline & $\begin{array}{l}\text { Trying to lift herself up on } \\
\text { the counter (16) }\end{array}$ & \\
\hline & $\begin{array}{l}\text { Re: } M \text { who just climbed up on } \\
\text { a chair (17) }\end{array}$ & $\begin{array}{l}\text { Putting a tiny figure on a } \\
\text { toy tree (17) }\end{array}$ \\
\hline & $\begin{array}{l}\text { Sitting up after lying on her } \\
\text { back (19) }\end{array}$ & $\begin{array}{l}\text { Putting something on coffee } \\
\text { table (19) }\end{array}$ \\
\hline & Climbing up on a chair (19) & $\begin{array}{l}\text { Putting a peg doll on top of } \\
\text { toy fire engine (19) }\end{array}$ \\
\hline & $\begin{array}{l}\text { Trying to climb on } \mathrm{M} \text { 's } \\
\text { lap }(20)\end{array}$ & Picking up a newspaper (20) \\
\hline & $\begin{array}{l}\text { Standing up in high chair } \\
(20)\end{array}$ & $\begin{array}{l}\text { Wanting Mary to lift her onto } \\
\text { a bed }(20)\end{array}$ \\
\hline & $\begin{array}{l}\text { When } C \text { arrives at top of } \\
\text { stairs }(21)\end{array}$ & Wanting $M$ to pick her up (21) \\
\hline
\end{tabular}

Note: utterances were produced just before, during, or just after the events indicated. $\mathrm{M}=$ Mother, $\mathrm{F}=$ Father, $\mathrm{C}=$ Child's sister.

up, and getting up in the morning. They also said up and down for caused motions, for example, when they wanted an adult to lift them up onto a higher surface or take them down from it, for picking up objects from the floor or putting them on raised surfaces, pushing or pulling things downward, and putting things down on the floor or other low surfaces. They also used up as a request to be picked up and held or carried, and both up and down for static situations, for example, up when pointing to the upper branches of a tree in a picture, and down when looking at a doll floating head down in the tub. This range of uses is consistent with that reported for other children in this age period.

English-speaking children acquirc up and down so early, and extend them so readily to many situations of vertical motion or orientation, that many investigators have assumed that vertical motion "up" and "down" are nonlinguistic notions. For example, Nelson (1974), reporting on a year-old child who extended up on the first day of its use "to all vertical movement of the child himself or of objects", proposed that "there is a core representation of this action concept... 
something like Vertical Movement" (p. 281). Similarly, Bloom (1973, p. 70) suggested that the early uses of up reflect the "notion of "upness"" and Gruendel (1977a) concluded that uses of $u p$ in her data support Bloom's proposal that " 'upness' is itself a true early-cognized or conceptualized relation". In a study of the development of relational words at the one-word stage, McCune-Nicolich (1981) found that up and down, along with several other words, emerged somewhat abruptly in the speech of five children, spread rapidly to a variety of contexts, and were less likely to be imitated than other words. She proposed that these early-learned relational words code "pre-established cognitive categories" in particular, operative knowledge of the late sensorimotor period to do with space, causality, sequence, and the like. She predicted that "since operative intelligence is a universal aspect of cognition, the same categories of meaning would be expected for all children, although various lexical items might be used to encode these" (p. 18).

When our attention is confined to English, it is plausible to think that children generate notions of vertical motion nonlinguistically and simply map them directly to up and down. But in cross-linguistic perspective, it is sobering to realize how neatly tuned these meanings are to the requirements of what is, after all, a language-specific system of expressing Path. Let us turn now to Korean to see whether children exposed to a different system express the same meanings, albeit mapped to different words.

\section{Korean}

\section{Words used to express motion}

Because we have fewer data from each Korean child than from our Englishspeaking subjects, we will often consider the children of a particular age period together. A summary of pooled data is presented in Table 7.

Like our English-speaking subjects, our Korean subjects began to refer to motion events between 14 and 16 months. The first productive words for motion of all four children in group I were the transitive Path verbs KKITA "fit" and/or PPAYTA "unfit". ${ }^{14}$ Typical contexts of use included putting Lego pieces together or taking them apart, and fitting plastic shapes into the holes of a shape box. By 17-18 months a number of other transitive Path verbs emerged: PWUTHITA "put one surface to another", which the children used for stickers and bandaids, KKA(K)TA "peel off", 15 NEHTA "put into a loose container", KKENAYTA "take out of loose container", and some "carrying" and "clothing" verbs. By

\footnotetext{
${ }^{14}$ The ending -TA marks the citation form of a verb in Korean. Verbs in the children's speech were suffixed instead with various modal endings, most typically - E (or -A), which is used in adult speech for requests or assertions. Thus, a child's rendering of KKITA "fit" would typically be KKI-E.

${ }^{15}$ At this early stage of development, the children did not differentiate phonologically between KKATA "take off covering layer or wrapper" and KKAKTA "take off covering layer with knife".
} 
Table 7. Early words for spontaneous and caused motion events in Korean children's speech ${ }^{\mathrm{a}}$

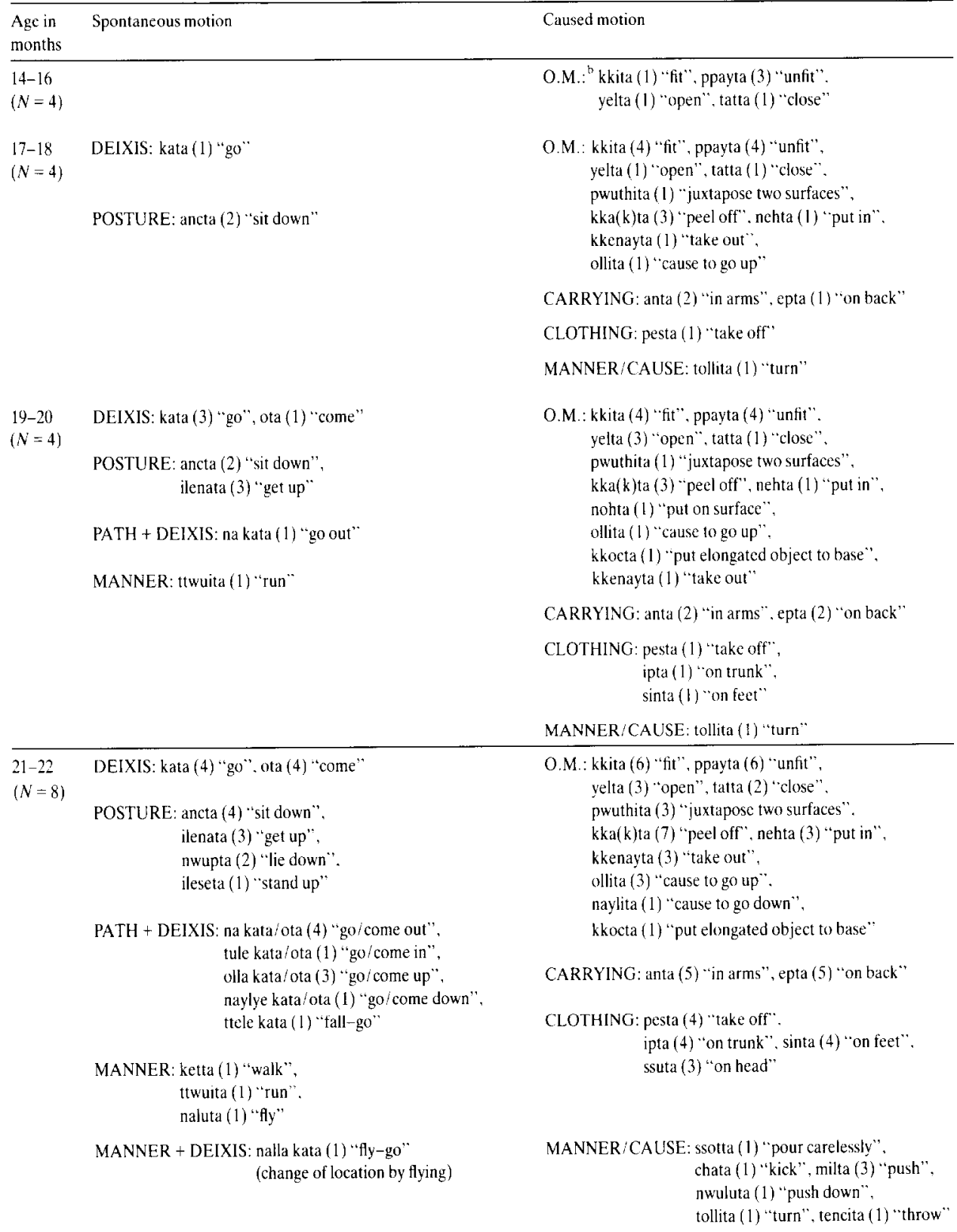


Table 7 continued.

\begin{tabular}{|c|c|c|}
\hline $\begin{array}{l}\text { Age in } \\
\text { months }\end{array}$ & Spontaneous motion & Caused motion \\
\hline $\begin{array}{l}23-24 \\
(N=8)\end{array}$ & $\begin{array}{l}\text { DEIXIS: kata (7) "go", ota (5) "come" } \\
\text { POSTURE: ancta (7) "sit down". } \\
\text { ilenata (4) "get up". } \\
\text { nwupta (3) "lie down", } \\
\text { ileseta (1) "stand up" } \\
\text { PATH + DEIXIS: na kata/ota (5) "go/come out", } \\
\text { tule kata/ota (4) "go/come in", } \\
\text { olla kata/ota (5) "go/come up", } \\
\text { naylye kata/ota (2) "go/come down" } \\
\text { MANNER: ttwuita (2) "run", } \\
\text { ttuta (1) "float". } \\
\text { ttelecita (1) "fall" }\end{array}$ & $\begin{array}{l}\text { O.M.: kkita (6) "fit", ppayta (6) "unfit", } \\
\text { yelta (7) "open", tatta (3) "close". } \\
\text { pwuthita (4) "juxtapose two surfaces", } \\
\text { kka(k)ta (7) "peel off", nehta (4) "put in", } \\
\text { kkenayta (3) "take out", } \\
\text { ollita (2) "cause to go up", } \\
\text { naylita (2) "cause to go down", } \\
\text { nohta (3) "put on surface", } \\
\text { kkocta (1) "put elongated object to base" } \\
\text { CARRYING: anta (6) "in arms", epta (4) "on back", } \\
\text { tulta (1) "in hands" } \\
\text { CLOTHING: pesta (6) "take off", } \\
\text { ipta (5) "on trunk", sinta (4) "on feet", } \\
\text { ssuta (2) "on head" } \\
\text { MANNER/CAUSE: tollita (1) "turn", } \\
\text { nwuluta (2) "push down". } \\
\text { tencita (2) "throw", } \\
\text { kkulta (1) "pull", } \\
\text { capta (2) "hold/catch" }\end{array}$ \\
\hline
\end{tabular}

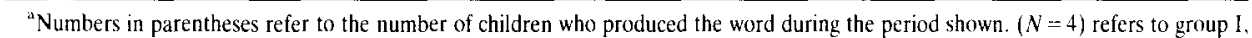
$(N=8)$ refers to groups I and II combined. For group I, each verb listed was produced by the child at least once during the recording scssion, and the mother reported that the child produced it more than once during the age period indicated. Fon group II. the verb was produced by the child at least once during the recording session.

'O.M. = verbs of object manipulation.

19-20 months, NOHTA "put on surface", KKOCTA "put elongated object to base", and OLLITA "cause to go up" were added, along with additional clothing verbs.

\section{Spontaneous versus caused motion}

As Table 7 shows, the Korean children used transitive Path verbs only for caused motion and never overgeneralized them to spontaneous motion; for example, they never said KKITA "fit" when they crept into a narrow space or KKENAYTA "take out of a loose container" when they got out of the bathtub. In fact they never violated the distinction between spontaneous and caused motion along a Path throughout the entire developmental period observed: no verb was used in contexts of both kinds. In comparison, recall that our Englishspeaking subjects used some Path particles for both spontaneous and caused motion by as early as 14-16 months, and many by 20 months. ${ }^{16} \mathrm{~A}$ major

${ }^{16}$ The English-speaking children did discriminate well between transitive and intransitive verbs. They never used a transitive verb such as take for spontaneous motion. Occasionally they used intransitive verbs for caused motion (see Table 5), but mostly in contexts where this is also acceptable in adult speech, e.g., fall when a Figure is dropped or knocked over and come (out/off, etc.) for manipulations of small objects (cf. adult utterances like "Will it come out?"). Errors such as "I come (=bring) it closer" (Bowerman, 1974) did not start until about age 2, and can be attributed to a learned rule, not ignorance that a verb is basically intransitive (Bowerman, 1974; Pinker, 1989). 
difference between children learning English and Korean, then, is in their willingness to extend Path words across the transitivity boundary.

Unlike English-speaking children, our Korean subjects at first focused almost exclusively on caused motion. In C's and E's speech, expressions for spontaneous and caused motion developed in parallel. In the Korean children's speech, intransitive motion verbs appeared much later than transitive motion verbs. As Table 7 shows, the children produced no intransitive verbs for Motion or Path at all between 14 and 16 months. At 17-18 months KATA "go" was used by one child. Two others may have also said KATA at this age according to their mothers, but, if so, it was far less productive than transitive motion verbs: the children did not say it during the recording sessions and the mothers" reports were not consistent from one session to the next. KA'l'A "go" and OTA "come" became productive only at 19 months. One child combined KATA with the Path verb NA "exit" (NA KATA "exit go; go out") during this period as a request to go outside. The other children began to combine KATA and OTA with Path verbs only at 21 months.

As discussed earlier, many transitive motion verbs of Korean conflate Motion not only with Path but also with information about Ground and sometimes Figure. The children's use of these verbs was generally appropriate, showing that they were sensitive to the incorporation of these elements. The sense that ground may be a component of a motion verb's meaning seemed to become particularly strong between 17 and 20 months. At this time the children distinguished two verbs of supporting/carrying according to the body part that serves as Ground (ANTA "put into arms to support/carry" vs. EPTA "put on back to support/ carry"), and they also began to distinguish clothing verbs according to the Ground body part: IPTA "put clothes on trunk", SINTA "put clothing (e.g., shoes, socks) on feet". SSUTA "put clothing on head" appeared at 21 months.

Combining Path verbs with Manner and Cause verbs

Our Korean subjects were rather slow to learn verbs like TENCITA "throw" and MILTA "push", which in adult speech can be used either alone or in combination with transitive Path verbs to express the Manner or Cause of a caused motion event. Only one such verb, TOLLITA "cause to turn", is attested up through 20 months, and it was produced by only one child. More verbs of this type began to come in at 21-22 months (see Table 7). But they were not combined with Path verbs, even though the children produced word combinations of other kinds. Caused motion cvents were expressed either with Path verbs or with Manner/Cause verbs, but not with both at once - a pattern characteristic of adult Korean as well, as discussed earlier.

Our Korean subjects contrast sharply with our English-speaking subjects in their slow acquisition of Manner/Cause verbs and their failure to combine them with Path verbs. Recall that in the age range 17-20 months, $C$ and $E$ expressed motion events with both Path particles and many different Manner/Cause verbs. 
and from 19-21 months they often combined the two elements, particularly when expressing caused motion (see Table 5). Such combinations are, of course, characteristic of English and other languages of its conflation type, as described by Talmy $(1975,1985)$.

\section{Motion "down" and "up"}

As discussed earlier, English-speaking children learn down and up so early, and extend them so readily to many events involving downward and upward motion, that many investigators have supposed that they are mapped directly to nonlinguistic sensorimotor notions of vertical motion "downward" and "upward". If this is so, Korean children - presumably equipped with similar nonlinguistic concepts - should seize on Korean words produced frequently in contexts involving vertical motion, and extend them frecly to other events involving vertical motion regardless of whether the motion is spontaneous or caused or whether it involves a change of location or posture. For example, they might initially say either OLLA KATA "go up" or OLLITA "cause to go up" for both spontaneous upward motions, including posture changes, and for caused upward motions. Similarly, they might say either NAYLYE KATA "go down" or NAYLITA "cause to go down" for getting down, sitting or lying down, putting things down, and as requests to be put down. Alternatively, they might select ANTA "pick up and support/carry in arms" to mean "up" in general. or ANCTA "sit down" to mean "down" in general.

This does not occur. Although ANTA "pick up and hold/carry in arms" and $\Lambda$ NCT $\Lambda$ "sit down" were produced by some of the children from 1718 months, they were never overextended to other situations involving vertical motion. The intransitive and transitive causative forms of OLL- "up" and NAYLY- "down" emerged very late compared to up and down in the speech of children learning English. The development of our four youngest subjects (group I) is shown in Table 8.

Among the children of group I, SN was, at 18 months, the youngest to produce one of these words - OLLITA "cause to go up". However, he made an intriguing error in the meaning he first assigned to it. When he was 17 months old his mother had said OLLITA when she was putting plates back in a kitchen cabinet high above the counter. SN apparently overlooked the "up" information embedded in this complex event and inferred that the word meant "put something in the location where it belongs"; for a month, he used the verb only for "putting away" events of many sorts, regardless of directionality, for example, putting a toy back in a container on the floor. He made this error at a time when he was learning a variety of transitive verbs - for example, clothing verbs - that include a Ground component. The acquisition of Ground-incorporating verbs may sensitize Korean children to the possibility that Ground may be relevant to the meaning of a new transitive motion verb. Only at 19 months did SN begin to use OLLITA for caused upward motion, for example, to ask his mother to lift him up onto a step. 
Table 8. Examples of NAYLY- ("descend") and OLL- ("ascend") in four Korean-speaking children

$\begin{array}{ll} & \begin{array}{l}\text { Spontancous motion } \\ \text { (age in months) }\end{array} \\ \text { AN: } & \text { NAYIYYE KATA (descend-go) } \\ & \text { Getting down from her high chair } \\ & (24) \\ \text { Getting down from counter (24) }\end{array}$

Caused motion

(age in months)

NAYLY-ITA (descend-causative)

Taking a plate down from table (24)

MK:

$-$

Getting down from her high chair

(26)

Going downstairs (26)

Getting down fronl a step (26)

OLLA KATA (ascend-go)

$\mathrm{AN}$ :

Climbing up on couch (24)

Climbing onto her bed (24)

Climbing up in her high chair (24)

MK:

SN:

Going upstairs (22)

Climbing up on a chair (22)

YN:

Climbing up in her high chair (26)
Taking an object down from counter (25)

Taking an object down from shelf (25)

Asking $M$ to pull her pants down (23)

Asking $M$ to pull her pants down (25)

Asking $\mathrm{M}$ to take her down from her high chair (25)

OLL-ITA (ascend-causative)

Putting an object up on the table (21)

Putting a toy on her leg while seated (22)

Putting her plate up on the counter (24)

Putting an object on the counter (26) Putting a toy car up on the shelf (27)

Putting toys back in their usual place (18) (not necessarily "up", sec text)

Wanting $M$ to put him in high chair (19)

Wanting $M$ to lift him onto the step in the bathroom (19)

Putting an object on the chair/ kitchen counter (20)

Asking $M$ to pull her pants up (26)

Asking $M$ to lift her up onto a stool (26) 
At 22 months he finally also began to say OLLA KATA "go up" in connection with spontaneous motions like getting on a chair.

OLLITA and OLLA KATA emerged even later in the speech of the other three children. The development of NAYLITA "cause to go down" and NAYLYE KATA "go down" is similar to that of OLLITA "cause to go up" and OLLA KATA "go up", but still slower, as shown in Table 8 . Although the Korean children were slow to use words comparable to $u p$ and down, this does not mean that they did not talk about events involving upward and downward motion. They did - but using verbs that classify these events on the basis of criteria other than their shared Path.

The late appearance of intransitive Path verbs is not restricted to OLLA KATA "go up" and NAYLYE KATA "go down", nor to these four youngest children of our sample. Of the eight children whose data at 21-22 months are shown in Table 7, only three said OLLA KATA/OTA "go/come up", only one said NAYLYE KATA "go/come down", only four said NA KATA/OTA "go/come out", and only one said TULE KATA/OTA "go/come in". We return to the question of why these verbs are so late in the discussion section.

\section{Discussion}

Although children learning English and Korean talk about similar motion events in the second year of life, they do not do so in similar ways. English-speaking children rely heavily on Path particles. They start out using some of these in restricted or idiosyncratic ways, but soon extend them to a wide range of spontaneous and caused motion events that share similar abstract Paths. By about 20 months they begin to combine them productively with verbs that specify the Manner, Cause, or Deictic aspects of the motion event.

Korean children use no words in these ways. Like Korean adults, they distinguish strictly between words for spontaneous and caused motion. Concentrating first on caused motion, they learn a variety of transitive verbs that conflate Path with notions of Figure and especially Ground, and extend them to different classes of motion events than are picked out by English-speaking children's Path particles. ${ }^{17}$ Their intransitive Path verbs are limited for many months to verbs of

\footnotetext{
${ }^{17}$ For example, they use the same verb (KKITA "fit") for putting a Figure into a tight container and attaching it to an outside surface (in vs. on for learners of English), and the same verb (PPAYTA "unfit") for the reverse of these actions (out vs. off). But they use different verbs for putting objects into tight versus loose containers (KKITA vs. NEHTA; both in for learners of English) or taking them out (PPAYTA vs. KKENAYTA; both out), for joining three-dimensional (KKITA), flat (PWUTHITA), or elongated (KKOCTA) Figures to a Ground (all in or on for learners of English, depending on whether there is containment), for putting clothing on the head (SSUTA), trunk (IPTA), or feet (SINTA; all on), and for being supported or carried in the arms (ANTA) or on the back (EPTA) (both up or carry).
} 
posture change. They do not acquire intransitive Path verbs for spontaneous motion "in", "out", "up", and "down" until long after English learners begin to use Path particles for spontaneous motion, and they are just as late on transitive verbs for caused motion "up" and "down". Once they do learn verbs for "up" and "down", they never overgeneralize them to posture changes or use them as requests to be picked up and carried, both favorite uses of up and down by English-speaking children.

These findings challenge the widespread view that children map spatial morphemes directly to their sensorimotor concepts of space, and suggest instead that children are guided in constructing spatial semantic categories by the language they are exposed to. We will elaborate on this interpretation shortly. But first let us try to rule out alternative interpretations that do not require crediting such young children with a language-specific semantic organization of space.

\section{Context-bound learning and homonyms}

Perhaps the look of language-specific semantic organization is an illusion. Maybe children just imitate the words they hear in particular contexts, and see no relationship between them. For instance, our subjects may have simply learned what to say when climbing onto a chair, when wanting to be picked up, and when getting into a standing posture. Learners of Korean would use three different verbs, while learners of English would say up in each case, but for both sets of children the word said in each context would be independent.

This hypothesis is easy to rule out. First, our subjects used spatial words creatively, extending them to many events for which they had never heard adults use them. Many of their novel uses were completely appropriate; for example, $1-11$ and $17-24$ in Table 9. Others were errors from the adult point of view, for example, $12-16$ and $25-34$. Errors show particularly clearly that children are not simply imitating what they have heard in particular contexts. They have often been interpretated as evidence that children rely on meanings generated independently of language (e.g., Nelson, 1974; see Bowerman, 1989, for discussion). But our subjects' errors seem to reflect problems of detail within spatial semantic systems that, in broad outline, were already language specific. For example, our Korean subjects knew that PPAYTA "unfit" had to do with taking something from a position of tight fit or attachment, but they sometimes overextended it to attachments of the wrong kind, for example, those involving flat surfaces (e.g., 32 in Table 9) or tight clothing or embrace (e.g., 25-28, 31). Similarly, our English-speaking subjects knew that in applied generally to "containment", but they tended to assimilate "position between" to this category $(14-15)^{18}$

\footnotetext{
${ }^{1 x}$ See also Bowerman (1978a, 1980) on overextensions of open and close to actions that adults would encode with on and off or together and apart.
} 
Table 9. Examples of novel uses of spatial words by learners of English and Korean between 15 and 25 months (age in months; errors are starred)

\begin{tabular}{|c|c|}
\hline \multicolumn{2}{|l|}{ ENGLISH } \\
\hline 1. ON & Putting a ladybug magnet on a can opener, C 16. \\
\hline $\begin{array}{l}\text { 2. ON + negative } \\
\text { head shake. }\end{array}$ & $\begin{array}{l}\text { Has just been told not to pull off a bit of paper stuck to } \\
\text { M's leg, but she wants it off, E } 18 \text {. }\end{array}$ \\
\hline 3. OFF & $\begin{array}{l}\text { Asking } \mathrm{M} \text { to remove a (nonremovable) upright pole from back } \\
\text { of her riding toy, } \mathrm{C} 17 \text {. }\end{array}$ \\
\hline 4. IN. TOY IN & $\begin{array}{l}\text { Trying to fit piece of camera into loop formed by pull-handle } \\
\text { of drawer, C } 21 \text {. }\end{array}$ \\
\hline 5. IN 'GAIN & $\begin{array}{l}\text { Trying to shove piece of toy furniture through door in doll } \\
\text { house, E } 18 \text {. }\end{array}$ \\
\hline 6. OUT & $\begin{array}{l}\text { Has just dipped hand into her glass of milk and taken it out } \\
\text { again; is now inspecting it, } C 17 \text {. }\end{array}$ \\
\hline 7. OUT & $\begin{array}{l}\text { Trapped behind toys in her room, she wants help in getting } \\
\text { out, E } 17 \text {. }\end{array}$ \\
\hline 8. SMOKE OUT & Watching steam coming out of vent in the ground, E $2 \mathrm{I}$. \\
\hline 9. DOWN & Pushing down head of neighbor's cat, C 17. \\
\hline 10. DOWN & Asking $\mathrm{M}$ to move chair from table to floor. E 16. \\
\hline 11. UP, DOWN & "Walking" her fingers up to her neck and back down, E 19. \\
\hline 12. ${ }^{*} \mathrm{OPEN}$ & Trying to separate two Frisbees, C 16 \\
\hline 13. *LOSE KNEES & Asking $\mathrm{M}$ to put her knces together. E 21 \\
\hline 14. ${ }^{*}$ MONIES ... IN & $\begin{array}{l}\text { Looking for coins she'd just stuffed down between two couch } \\
\text { cushions, E } 19 \text {. }\end{array}$ \\
\hline 15. ${ }^{*}$ IN & Putting ping-pong ball between knees, E 20 . \\
\hline 16. ${ }^{*} \mathrm{OFF}$ & Asking $M$ to unfold a newspaper, $C 15$ \\
\hline \multicolumn{2}{|l|}{ KOREAN } \\
\hline 17. PPAYTA & $\begin{array}{l}\text { Trying to pull out the string from the end of the toy fire hose, } \\
\text { AN } 15 \text {. }\end{array}$ \\
\hline 18. PPAYIA & $\begin{array}{l}\text { Trying to take out Investigator's (Inv.'s) jigsaw puzzle game } \\
\text { from tight-fitting box, AN } 15 \text {. }\end{array}$ \\
\hline 19. PPAYTA & Asking Inv. to take lid off her (Inv,'s) pill box, SN 19 \\
\hline 20. PPAYTA & Taking flute apart, HS 22. \\
\hline 21. PPAYTA & Trying to take out pencil stuck through paper, HS 22 . \\
\hline 22. KKITA & Putting doll into tight-fitting seat of small horse, AN 17 . \\
\hline 23. KKITA & Fitting a train into its wooden base (Inv.'s new toy). MK 17 . \\
\hline 24. KKITA & Watching Inv. put video cassette in camcorder, TJ 23. \\
\hline 25. ${ }^{*}$ PPAYTA & Trying to take bib/shirt off, AN 16. (PESTA is appropriate.) \\
\hline 26. *PPAYTA & Asking $M$ to take his bib/shirt off, SN 18. (PESTA) \\
\hline 27. *PPAYTA & Asking $M$ to take her shirt off. TJ 18. (PESTA) \\
\hline 28. *PPAYTA & Wanting to get toy away from sister, HS 22. (CWUTA "give"). \\
\hline 29. *PPAYTA & Asking someone to peel a banana, HS 25. (KKATA) \\
\hline 30. ${ }^{*}$ KKITA & Sticking fork into apple, TJ 23. (KKOCTA) \\
\hline 31. *KKITA & Re: Being held tight by an adult, PL 22. (ANTA) \\
\hline 32. ${ }^{*} \mathrm{KKITA}$ & $\begin{array}{l}\text { Attaching magnetic fish to magnetic mouth of duck. TJ } 25 \text {. } \\
\text { (PWUTHITA) }\end{array}$ \\
\hline 33. *OLLITA & $\begin{array}{l}\text { Putting toys back in place, SN } 18 \text {. (KACTA TWUTA "bring/ } \\
\text { take back") }\end{array}$ \\
\hline 34. ${ }^{*} \mathrm{KKOCTA}$ & Putting a Lego picce onto another, SN 20. (KKITA) \\
\hline
\end{tabular}


Second, the "context-bound" explanation flies in the face of much work on early word use by other investigators. Although many researchers have noted that first words are often tied to specific contexts, most assume that this phase is short-lived. According to some, there is a shift to a more symbolic basis for word meanings around the middle of the second year (e.g., McShane, 1979; Nelson \& Lucariello, 1985); others argue that many or most words are never significantly context bound at all (Barrett, Harris, \& Chasin, 1991; Harris, Barrett, Jones, \& Brookes, 1988; Huttenlocher \& Smiley, 1987). The move away from contextbased word use is often assumed to show that the child has come to rely on her own nonlinguistic conceptualizations of objects and events (e.g., Barrett et al., 1991; Nelson \& Lucariello, 1985). Our subjects began to use a variety of spatial words in flexible and context-free ways between 16 and 20 months. Ironically, though, this development went paired with striking language specificity, which clashes with the hypothesis that the children were now starting to rely on their own nonlinguistic conceptions of space.

But perhaps we can reconcile evidence for creativity with the idea that children learn words for rather specific meanings. Suppose children share a repertoire of nonlinguistic spatial concepts that, although narrow, are broad enough to accommodate new instances. And suppose they associate each concept with a different word. For the hypothetical concepts "sitting down", "lying down", "going down", and "putting down", Korean children would learn four different words, while English speakers would learn four words all pronounced down, perhaps as reduced versions of more complete English verb phrases like sit down, lie down, go down, and put down. Let us call this the "homonym" hypothesis. ${ }^{19}$

This hypothesis requires a close look. Even for adult English speakers, some uses of the same Path particles are probably unrelated, and other uses only loosely related via a network of polysemes (see Brugman, 1981; Herskovits, 1986; Lakoff, 1987; Langacker, 1987; Lindner, 1981). And some uses that are related for adults might well start out as distinct for children, only coming together later as learners discover abstract similarities across situations to which the same particles are applied. We ourselves have assumed that English-speaking children's uses of on and off for actions with light switches and water faucets are independent of the spatial uses of these morphemes, and so have left them out of our analyses. But most of the differences we have found between children learning English and Korean do not submit easily to the homonym hypothesis.

The hypothesis requires us to assume that whenever learners of one language use a single word for situations that learners of another language distinguish with two or more words, the single word actually has two or more independent meanings. Sometimes this seems plausible; for example, it is not too jarring to

\footnotetext{
${ }^{19}$ We are grateful to Eve Clark for making us worry about this possibility, and for her insightful fecdback on our attempts to deal with it.
} 
posit homonymous downs for "sitting down" and "lying down". But do we really want to have to separate down for climbing down from a chair from down for being lifted down from the chair, and in for climbing into a tub from in for putting something into the tub? (Recall that the Korean children used different path verbs for spontaneous and caused motion events.) And do we feel comfortable with homonymous ins for putting a book in a tight-fitting box versus a looser box (KKITA vs. NEHTA for Korean children), and homonymous outs for the reverse of these actions (PPAYTA vs. KKENAYTA) ${ }^{20}$ These uses are so consistent with the central spatial meanings of these particles that it has never occurred to previous investigators that they might be independent acquisitions.

In fact there are good reasons to believe they are not. Once particular spatial words emerge in children's speech they often spread rapidly to new uses, which supports the intuition that they are interrelated. For example, our subject $\mathrm{C}$ first said in at 19 months for coming indoors (="come/go in"). Within a few days she also used it for "put in" actions like putting a sock in the laundry basket and a bead in a container, and for static containment, as when playing with an unopened thermometer package. E first said up at 16 months when she stood up in the car (="stand up"); within a few days she also used it for "go/get up" events like climbing up a slide, stepping up on a little chair, and trying to pull herself up by the kitchen counter, as a request to be lifted (="pick up"), and for static "upness", for example, for a picture of a cat sitting on a broomstick at a higher angle than a witch. Similar rapid extension patterns for up have been reported by Bloom (1973, p. 88), Leopold (1939), and Nelson (1974). Children's speed in generalizing especially up and down across diverse contexts is well recognized, and has often been cited to support the hypothesis that these words are mapped to unitary concepts of vertical motion (e.g., McCune-Nicholich, 1981). While we disagree that the route between nonlinguistic concepts and spatial word meanings is as direct as this, we concur that core uses (though not necessarily every use) of the various Path particles are related for the child.

\section{Language-specific semantic learning}

The differences we have found between learners of English and Korean cannot be ascribed to word meanings that are highly context bound or based on very narrow nonlinguistic spatial concepts. They constitute real differences in the children's

\footnotetext{
${ }^{210}$ Note also that adult English routinely applies put in and take out to most "tight" and "loose" manipulations with containers, so lcarners of English are probably not relying on distinct underlying verb phrases when they say in or out for these acts. If English speakers find it strange to split up the core meanings of $i n$ and $o u t$, Korean speakers find it equally strange to imagine that when a child says KKITA for fitting a figure "into" or "onto" a tight ground, or PPAYTA for taking it "out of" or "off", these uses are independent for him.
} 
semantic organization - differences that correspond directly to the way spatial meanings are structured in the language the children are learning.

Fnglish isolates Path as a recurrent component of motion events in an exceptionally clear and consistent way. With its system of Path particles, it encourages learners to identify abstract notions of Path that are indifferent to whether the Figure moves spontaneously or is caused to move, and to details about the shape or identity of the Figure and Ground objects. Korean does not single out Path as a separate component of motion events as clearly and consistently as English. It uses Path verbs that differ in both form and meaning for spontancous and caused motion (except for motion "up" and "down"), and - for caused motion and posture verbs - it combines information about Path with information about the shape or identity of the Figure and Ground objects. Korean children, then, are not prompted to analyze out Path as an abstract component of motion events as strongly as are learners of English, and this may account for their delay in acquiring those Path verbs that do express Path in relatively pure form. Instead, they are encouraged to classify motion events on the basis of Path meanings admixed with causativity and properties of the Figure and Ground. ${ }^{21}$

In rejecting the hypothesis that children's early spatial words are mapped to nonlinguistic concepts, we do not mean that nonlinguistic spatial cognition plays no role in spatial semantic development. Clearly it does. For example, across languages, children learn words for topological relationships (e.g., on and in) before words for projective relationships (e.g., in front of and behind) (Johnston \& Slobin. 1979). This bias - also shown by our subjects - presumably reflects the order of emergence of nonlinguistic spatial understanding. Children also make certain errors even on words for topological relationships (see Table 9), which suggests that some topological distinctions are more difficult than others, presumably for cognitive reasons. We must, then, posit an interaction between language input and cognitive development. But how does this interaction take place?

More than thirty years ago Brown proposed that for language learners, "a speech invariance is a signal to form some hypothesis about the corresponding invariance of referent" (1958, p. 228). Our findings confirm this. Even very young children must be sensitive to the way adults use spatial words across contexts otherwise they could not learn to classify spatial referents in a language-specific way so early. But we still know little about how children track uses of the same form over time, and how they generate and modify hypotheses about the adult's intended "invariance of referent".

\footnotetext{
${ }^{21}$ These claims are intended to apply only to children's organization of space for purposes of talking about it ("thinking for speaking", to borrow a phrase from Slobin, 1991). We take no stand here on whether the proposed semantic differences between learners of English and Korean have any Whorfian consequences for nonlinguistic spatial thought. Such effects would be compatible with our findings, but are not entailed by them.
} 
A prerequisite for generating hypotheses about spatial words is to have some system for representing space. But "both the nature of the initial system for internally describing space and the way in which such a system can be modified by experience... remain as mysterious as ever" (Pylyshyn, 1977, p. 174). Many researchers have approached this problem by positing a set of semantic primitives or "privileged notions": an inborn mental vocabulary of distinctions or components drawn on in acquiring spatial words, such as verticality, region, inclusion, support, contact, attachment, Figure, Ground, Path or direction, and object dimensionality (point, line, plane, or volume) (Bierwisch, 1967; H. Clark, 1973; Jackendoff, this issue; Jackendoff \& Landau, 1991; Miller \& Johnson-Laird, 1976; Olson \& Bialystok, 1983; Talmy, 1983). Spatial primitives would no doubt interact with other privileged notions such as, for verbs, causality and manner (Gropen et al., this volume; Jackendoff, 1983, 1990; Pinker, 1989). The repertoire of primitives would be the same for all languages, although they might be combined in different ways.

This approach has a number of advantages. Most important for us, it can help explain how children home in so quickly on language-specific spatial meanings: they do not need to generate endless hypotheses about what aspects of spatial relationships might be relevant in their local language, but only to choose and combine primitives in the right way. The approach also allows us to reconcile language specificity with errors: by hypothesis, children are relatively accurate on words based on (combinations of) features that are highly accessible, but make errors on words with features that are less salient or emerge only later in cognitive development (Bowerman, 1985; Slobin, 1985). ${ }^{22}$ But it will take serious work to make the semantic primitives approach truly explanatory rather than simply programmatic.

One problem is that it may be difficult to make principled distinctions between meanings that are "privileged" for space (or any other semantic domain) and other conceptual distinctions a speaker can make (see also Bolinger, 1965; E. Clark, 1983). For instance, notions like "verticality", "inclusion", and "support" make plausible-sounding spatial primitives, whereas notions like "arms", "head", "back", "feet", and "clothing item" do not. But notions of both kinds played a role in the meaning of our subjects' earliest spatial words.

One attempt to get a better grip on what components should be considered "privileged" has been to restrict the notion of primitives to the "grammaticized" portion of language. According to this approach, open-class words like nouns and verbs may incorporate any kind of meaning, no matter how idiosyncratic or culturally specific. In contrast, closed-class morphemes like inflections, particles,

\footnotetext{
${ }^{22}$ Of course, this explanation is circular unless we can find some independent way to predict how accessible a feature is. See Bowerman and Gentner (in preparation) for a cross-linguistic (DutchEnglish) test of the prediction that the ease of spatial semantic distinctions for children is linked to the frequency with which the distinctions are marked in the world's languages.
} 
and prepositions draw on a much more restricted set of meanings (Slohin, 1985; Talmy, 1983, 1985). In particular, closed-class spatial morphemes are insensitive to most properties of the Figure and Ground objects, such as exact shape, angle, and size, and instead schematize spatial situations in terms of more abstract topological properties (Talmy, 1983; see also Jackendoff \& Landau, 1991). ${ }^{23}$ If information of this kind comes built in, English learners will not waste time hypothesizing that closed-class items like up or on apply only to Figures or Grounds of a certain kind (Landau \& Stecker, in press). Korean learners, however, cannot rule out this possibility when they meet open-class items like the verb SINTA "put a clothing item on the feet or legs".

But this solution raises new problems. First, if meanings like "clothing item" and "feet" are not semantic primitives but have to be constructed from experience, it should take longer for Korean children to acquire spatial verbs that incorporate them than for English-speaking children to acquire Path particles that do not. But this is not the case. Second, we would need to explain how children between about 17 and 20 months - the period when our subjects were acquiring language-specific meanings for spatial morphemes-determine whether a morpheme is a member of an open or a closed class, and so decide on what kinds of hypotheses they should consider.

Finally, the semantic primitives approach probably underestimates what the child must learn about meaning. When meaning components are assumed to be built in, there is no need to explain them further (except, of course, at the genetic level). For some candidate primitives, this may be correct. For example, both English and Korean learners seem to recognize that different expressions may be needed for spontaneous and caused motion, and they do not extend words across this boundary unless - as for English particles - this use is demonstrated in the input. This is consistent with reports that children learning Japanese (Rispoli, 1987) and Quiché Mayan (Pye, 1985) identify verbs as transitive or intransitive from the start, and suggests that a full-blown sensitivity to caused versus spontaneous (or to transitive vs. intransitive) may be present in children from the outset of language acquisition. For other candidate primitives, however, experience may have significant "sharpening" effects (along lines discussed by Bornstein, 1979, for perceptual features). Let us consider the notion "Path" as an example.

We assume that learners of English and Korean have the same prelinguistic potential for identifying Path as an independent component of motion events. But

\footnotetext{
${ }^{23}$ Levinson (1991) has challenged this argument with data from Tzeltal. In this Mayan language. spatial relationships comparable to in and on are expressed with a closed-class set of "positional" verbs that predicate "to be located" of Figures of different types. Far from being abstract and purely topological, these verbs distinguish Figures on the basis of shape, size, and in some cases identity; for example, different verbs are needed for predicating spatial location of a wide-mouthed vessel, a narrow-mouthed vessel, an inverted object with flat side down (c.g., a lump of dough), a small sphere, a large sphere, things sitting bulging in a bag, objects leaning at various angles, and so on.
} 
we have suggested that the structure of English encourages children to develop this potential more than the structure of Korean - to actually carry out this kind of analysis. Why should we think this? Why not simply assume that both sets of children have a fully developed notion of Path from the beginning, along with some candidate instantiations of it like motion "up" and "down"? Our reason for doubt is that our Korean subjects were so late to acquire "pure" Path markers of Korean like the intransitive verbs OLL- "ascend", NAYL- "descend", TUL"enter", NA "exit", and the transitive verbs OLLITA and NAYLITA "cause to ascend/descend". They began to use these verbs only several months after acquiring verbs in which Path is conflated with information about the Figure and/or the Ground, and months after our English learners had acquired words like up, down, in, and out.

This delay is hard to explain if we assume that Korean and English learners both begin with a fully developed ability to isolate Path from complex motion events. $^{24}$ However, it is interpretable if we assume that children do not have a fully developed notion of Path, but rather are selectively prompted by the structure of the input to develop their skill at this analysis. Children learning English are systematically shown how to isolate a few recurring kinds of Path, and they learn how to do this quickly. Children learning Korean, in contrast, meet Path mostly conflated with notions of spontaneous or caused motion and often with specific properties of the Figure and Ground as well, so it takes them longer to realize that Path can sometimes be extracted and receive its own marking. If this analysis is correct, a danger of the "semantic primitives" approach is that by supplying the child with components that are "ready to go", it may cause us to overlook subtle learning processes promoted by the structure of the language being acquired.

In conclusion, we have shown that the meanings of children's early spatial words are language specific. This means that language learners do not map spatial

\footnotetext{
${ }^{2+}$ One attempt to do so would be to say that Korean learners are just as sensitive as English learners to path, but that they have more trouble with the superficial problem of identifying the morphemes to express it with (we are following the logic of Slobin, 1973, here). In particular, English Path particles often occur sentence-finally and can receive heavy stress, both properties known to facilitate acquisition of a form. In contrast, the Korean intransitive "pure" path verbs are usually pre-final, followed by KATA "go" or OTA "come". This account does not go through, however. Most critically, it does not explain why the transitive "pure" path verbs OLLITA and NAYLITA "cause to ascend/descend" are just as delayed as the intransitive "pure" path verbs, even though they are not followed by deictic verbs and are identical in their positioning to KKITA "fit" and other transitive path verbs that are learned much earlier. It is also doubtful whether the intransitive "pure" path verbs are perceptually less salient than early-learned transitive path verbs. In caregivers" speech, verbs of both kinds receive major stress and are typically followed by further unstressed morphemes such as the modal markers CWF "do something for someone" or PWA "try". For example, OLL- "ascend" might appear in a phrase like fólaka) (OLL-A KA) "ascend go; go up" or lólakapwa (OLL-A KA PWA) "try to go up", and KKITA "fit" in a phrase like [kkiepwa] (KKI-E PWA) "try to put it in" or [kkiecwe] (KKI-E CWE) "shall I put it in for you?" In both cases, the path verbs are stressed but nonfinal, which makes them similar in perceptual salience.
} 
words directly onto nonlinguistic spatial concepts, as has often been proposed, but instead are sensitive to the semantic structure of the input language virtually from the beginning. How children figure out language-specific spatial categories remains a puzzle. Although an appeal to semantic primitives offers some help, it leaves many questions unanswered. One thing seems clear, however: children could not learn language-specific spatial meanings as quickly as they do unless they have some good ideas about what to look for.

\section{References}

Aske, J. (1989). Path predicates in English and Spanish: A closer look. Berkeley Linguistics Society Papers, 15, 1-14.

Barrett, M., Harris, M. \& Chasin, J. (1991). Early lexical development and maternal speech: A comparison of children's initial and subsequent uses of words. Journal of Child Language, 18 , $21-40$.

Bavin. E. (1990). Locative terms and Warlpiri acquisition. Ioumal of Child Language, 17, 43-66.

Berman, R., \& Slobin, D.I. (1987). Five ways of learning how to talk about events: A crosslinguistic study of children's narratives. Berkeley Cognitive Science Report, 46: Berkeley, CA.

Bicrwisch. M. (1967). Some semantic universals of German adjectivals. Foundations of Language, .3. $1-36$.

Bloom, L. (1973). One word at a time. The Haguc: Mouton.

Bloom, L., Lightbown, P., \& Hood, L. (1975). Structure and variation in child language. Monographs of the Society for Research in Child Development, 40 (scrial no. 160).

Bolinger, D. (1965). The atomization of meaning. Language, 41, 555-573.

Bornstein, M.H. (1979). Perceptual development: Stability and change in feature perception. In M.H. Bornstein \& W. Kessen (Eds.), Psychological development from infancy: Image to intention. Hillsdale, NJ: Erlbaum

Bowerman, M. (1974). Learning the structure of causative verbs: A study in the relationship of cognitive, semantic, and syntactic development. Papers and Reports on Child Language Development, 8, 142-178.

Bowerman, M. (1976). Semantic factors in the acquisition of rules for word use and sentence construction. In D.M. Morehead \& A.E. Morehead (Eds.), Normal and deficient child language. Baltimore: University Park Press.

Bowerman, M. (1978a). The acquisition of word meaning: An investigation into some current contlicts. In N. Waterson \& C. Snow (Eds.). The development of communication. New York: Wiley.

Bowerman. M. (1978b). Systematizing semantic knowledge: Changes over time in the child's organization of word meaning. Child Development, 49, 977-987

Bowerman, M. (1980). The structure and origin of semantic categories in the language-lcarning child. In M.L. Foster \& S.H. Brandes (Eds.), Symbol as sense. New York: Academic Press.

Bowerman, M. (1985). What shapes children's grammars? In D.I. Slobin (Ed.). The cross-linguistic study of language acquisition. Vol. 2: Theoretical issues. Hillsdale, NJ: Erlbaum.

Bowerman, M. (1989). Learning a semantic system: What role do cognitive predispositions play? In M.L. Rice \& R.L. Schiefelbusch (Eds.), The teachability of language. Baltimore: Brooks.

Bowerman, M. (1991). The origins of children's spatial semantic categories: Cognitive vs. linguistic determinants. Paper presented at Wenner-Gren symposium "Rethinking linguistic relativity", Ocho Rios, Jamaica. (To appear in J.J. Gumperz \& S.C. Levinson (Eds.), Rethinking linguistic relativity.)

Bowerman, M. \& Choi, S. (in preparation)

Bowerman, M., \& Gentner, D. (in preparation). 
Brown, R. (1958). Words and things. New York: Free Press.

Brown, R. (1973). A first language: The early stages. Cambridge, MA: Harvard University Press.

Brugman, C. (1981). Story of over. M.A. thesis, University of California at Berkeley. Available from the Indiana University Linguistics Club.

Casad, E., \& Langacker, R. (1985). "Inside" and "outside" in Cora grammat. International Journal of American Linguistics. 51. 247-281.

Choi, S. (1991). Early acquisition of epistemic meanings in Korean: A study of sentence-ending suffixes in the spontaneous speech of three children. First Language, 11, 93-119.

Clark, E.V. (1973). Non-linguistic strategies and the acquisition of word meanings. Cognition, 2, $161-182$

Clark, E.V. (1983). Meanings and concepts. In J.H. Flavell \& E.M. Markman (Eds.), Mussen handbook of child psychology. Vol. 3: Cognitive development. New York: Wiley.

Clark, H.H. (1973). Space, time, semantics, and the child. In T. Moore (Ed.). Cognitive development and the acquisition of language. New York: Academic Press.

Currigan, R. Halpern, E., Aviezer, O., \& Goldblatt, A. (1981). The development of three spatial concepts: In, on, under. International Joumal of Behavioral Development, 4, 403-419.

Cromer, R.F. (1974). The development of language and cognition: The cognition hypothesis. In B. Foss (Ed.). New perspectives in child development. Harmondsworth. Middlesex: Penguin.

Delancey, S. (1985). The analysis-synthesis-kexis cycle in Tibeto-Burman: A case study in motivated change. In J. Haiman (Ed.), Iconicity in syntax. Amsterdam: Benjamins.

Dromi, E. (1987). Early lexical development. Cambridge, UK: Cambridge University Press.

Farwell, C. (1977). The primacy of "goal" in the child's description of motion and location. Papers and Reports on Child Language Development. 16. 126-133.

Gentner, D. (1982). Why nouns are learned before verbs: Linguistic relativity versus natural partitioning. In S.A. Kuczaj II (Ed.), Language development. Vol. 2: Language, thought, and culture. Hillsdale, NJ: Erlbaum.

Gibson, E.J., \& Spelke. E.S. (1983). The development of perception. In J.H. Flavell \& E.M. Markman (Eds.), Mussen handbook of child psychology. Vol 3: Cognitive development. New York: Wiley.

Gopnik. A. (1980). The development of non-nominal expressions in 12-24 month old children. Unpublished doctoral dissertation, Oxford University.

Gopnik. A., \& Choi, S. (1990). Do linguistic differences lead to cognitive differences? A crosslinguistic study of semantic and cognitive development. First Language, 10, 199-215.

Goprik, A., \& Meltzoff, A. (1986). Words, plans, things, and locations: Interaction between semantic and cognitive development in the one-word stage. In S.A. Kuczaj II \& M.D. Barrett (Eds.), The development of word meaning. Berlin: Springer-Verlag.

Greentield, P., \& Smith, J. (1976). The structure of communication in early language development. New York: Academic Press.

Gruendel. J. (1977a). Locative production in the single word utterance period: A study of up-down, on-off, and in-out. Paper presented at the Biennial Meeting of the Society for Research in Child Development. New Orleans, 1977.

Gruendel, J. (1977b). Referential extension in early language development. Child Development. 48. $1567-1576$

Halpern, E.. Corrigan, R.. \& Aviezer, O. (1981). Two types of "under"? Implications for the relationship between cognition and language. International Journal of Psycholinguistics, 8 $4(24), 36-57$.

Harris, M., Barrett, M., Jones, D., \& Brookes, S. (1988). Linguistic input and early word meaning. Journal of Child Language, 15, 77-94.

Herskovits, A. (1986). Language and spatial cognition: An interdisciplinary study of the prepositions in English. Cambridge, UK: Cambridge University Press.

Huttenlocher, J.. \& Smiley, P. (1987). Early word meanings: The case of object names. Cognitive Psychology, 19, 63-89.

Huttenlocher. J., Smiley, P., \& Charney, R. (1983). Emergence of action categories in the child: Evidence from verb meanings. Psychological Review, 90, 72-93. 
Ingram, D. (1971). Transitivity in child language. Language, 47, 888-909.

Jackendoff, R. (1983). Semantics and cognition. Cambridge, MA: MIT Press.

Jackendoff, R. (1990). Semantic structures. Cambridge, MA: MIT Press.

Jackendoff, R., \& Landau, B. (1991). Spatial language and spatial cognition. In D.J. Napoli \& J. Kegl (Eds.). Bridges between psychology and linguistics: A Swarthmore Festschrift for Lila Gleitman. Hillsdale, NJ: Erlbaum.

Johnston, J., \& Slobin. D.I. (1979). The development of locative expressions in English, Italian, Serbo-Croatian and Turkish. Journal of Child Language, 6, 547-562.

Lakoff, G. (1987). Women, fire, and dangerous things: What categories reveal about the mind. Chicago: University of Chicago Press.

Langacker, R.W. (1987). Foundations of cognitive grammar. Vol. 1: Theoretical prerequisites. Stanford. $\mathrm{C} \wedge$ : Stanford University Press.

Landau, B., \& Stecker, D.S. (in press). Objects and places: Syntactic geometric representations in early lexical learning. Cognitive Development.

Lee, H.B. (1989). Korean grammar. New York: Oxford University Press.

Leopold, W. (1939). Speech development of a bilingual child (Vol. 1). Evanston, IL: Northwestern University Press.

Levin. B. (1985). Lexical semantics in review: An introduction. In B. Levin (Ed.), Lexical semantics in review. Lexicon Project Working Papers, No. 1. Cambridge, MA: MIT Center for Cognitive Science.

Levine, S.C., \& Carey, S. (1982). Up front: The acquisition of a concept and a word. Journal of Child Language, 9, 645-657.

Levinson, S.C. (1991). Relativity in spatial conception and description. Paper presented at WennerGren symposium "Rethinking linguistic relativity", Ocho Rios, Jamaica. (To appear in J.J. Gumperz \& S.C. Levinson (Eds.), Rethinking linguistic relativity.)

Lindner, S. (1981). A lexico-semantic analysis of verb-particle constructions with up and out. Unpublished doctoral dissertation, University of California at San Diego. Available from the Indiana University Linguistics Club.

McCune-Nicolich, L. (1981). The cognitive bases of relational words in the single-word period. Journal of Child Language, 8, 15-34.

McShane, I. (1979). The development of naming. Linguistics, 17. 879-905.

Miller, G.A., \& Johnson-Laird, P.N. (1976). Language and perception. Cambridge, MA: Belknap Press of Harvard University Press.

Miller. W., \& Ervin. S. (1964). The development of grammar in child language. In U. Bellugi \& R. Brown (Eds.), The acquisition of language. Monographs of the Society for Research in Child Development, 29.92, 9-34.

Nelson, K. (1974). Concept, word, and sentence: Interrelations in acquisition and development. Psychological Review, 81, 267-285.

Nelson, K., \& Lucariello, J. (1985). The development of meaning in first words. In M.D. Barrett (Ed.), Children's single-word speech. New York: Wiley.

Olson, D.R., \& Bialystok, E. (1983). Spatial cognition: The structure and development of the mental representation of spatial relations. Hillsdale, NJ: Erlbaum.

Piaget, J., \& Inhelder, B. (1956). The child's conception of space. London: Routledge \& Kegan Paul.

Pinker, S. (1989). Learnability and cognition: The acquisition of argument structure. Cambridge, MA: MIT Press.

Pye, C. (1985). The acquisition of transitivity in Quiché Mayan. Papers and Reports on Child Language Development, 24, 115-122.

Pylyshyn. L.W. (197/). Children's internal descriptions. In J. Macnamara (Ed.), Language learning and thought. New York: Academic Press.

Rispoli, M. (1987). The acquisition of the transitive and intransitive action verb categories in Japanese. First Language, 7, 183-200.

Schlesinger, I.M. (1977). The role of cognitive development and linguistic input in language acquisition. Journal of Child Language. 4, 153-169.

Slobin, D.I. (1973). Cognitive prerequisites for the development of grammar. In C.A. Ferguson \& 
D.I. Slobin (Eds.), Studies of child language development. New York: Holt, Rinehart \& Winston.

Slobin, D.I. (1985). Crosslinguistic evidence for the language-making capacity. In D.I. Slobin (Ed.), The crosslinguistic study of language ucquisition, Vol. 2: Theoretical issues. Hillsdale, NJ: Eribaum.

Slobin, D.I. (1991). Learning to think for speaking: Native language, cognition, and rhetorical style. Paper presented at Wenner-Gren symposium 'Rethinking linguistic relativity", May, Ocho Rios, Jamaica. (To appear in J.J. Gumperz \& S.C. Levinson (Eds.). Rethinking linguistic relativity.)

Talmy, L. (1975). Semantics and syntax of motion. In J. Kimball (Ed.), Syntax and semantics. New York: Academic Press.

Talmy, L. (1983). How language structures space. In H. Pick \& L. Acredolo (Eds.), Spatial orientation: Theory, research, and application. New York: Plenum.

Talmy, L. (1985). Lexicalization patterns: Semantic structure in lexical forms. In T. Shopen (Ed.), Language typology and syntactic description, Vol. III: Grammatical categories and the lexicon. Cambridge, UK: Cambridge University Press.

Tomasello, M. (1987). Learning to use prepositions: A case study. Journal of Child Language, 14, 79-98.

Van Geert, P. (1985/6). In, on, under: An essay on the modularity of infant spatial competence. First Language, 6, 7-28. 